Research Report No. 4/2008

\title{
Diverse Persuasion(s): From Rhetoric to Representation (and Back Again to Rhetoric) in International Human Rights Interpretation
}

Craig Scott

Osgoode Hall Law School of York University

Follow this and additional works at: http:// digitalcommons.osgoode.yorku.ca/clpe

\section{Recommended Citation}

Scott, Craig, "Diverse Persuasion(s): From Rhetoric to Representation (and Back Again to Rhetoric) in International Human Rights Interpretation" (2008). Comparative Research in Law \& Political Economy. Research Paper No. 4/2008.

http://digitalcommons.osgoode.yorku.ca/clpe/178 


\section{Comparative Research in Law \& Political Economy}

\section{Craig Scott}

Diverse Persuasion(s): From Rhetoric to Representation (and Back Again to Rhetoric) in International Human Rights Interpretation $\odot$

EDTORS: Peer Zumbansen (Osgoode Hall Law School, Toronto, Director, Comparative Research in Law and Political Economy, York University), J ohn W. Cioffi (University of California at Riverside), Lindsay Krauss (Osgoode Hall Law School, Toronto, Production Editor) 

CLPE Research Paper 04/2008

Vol. 04 No. 01 (2008)

\title{
Craig Scott
}

\section{Diverse Persuasion(s): From Rhetoric to REPRESENTATION (AND BACK AgAIN TO RHETORIC) IN INTERNATIONAL HUMAN RIGHTS INTERPRETATION}

\begin{abstract}
This article proceeds from a way of thinking about legal-rights reasoning that is grounded in the rhetorical tradition. In light of questions of political legitimacy and personal ethics, a central premise of the article is that the rhetorical enterprise must situate itself within a paradigm of dialogic communication in which mutual persuasion is the orientation to argument and the quest for intersubjective validation of claimed premises, lines of argument, and conclusions is the purposive mode. The first step in the article is to move from a general conception of law as a field of rhetoric to an account of how such a conception can be a useful way of thinking about both the nature of (human) rights - assisted by the analytical account of the nature of rights advanced by Joseph Raz - and the interpretive processes of meaning-giving that go on within the international human rights treaty orders. The article then develops an account of representational diversity that builds on previous work on a notion of "interactive diversity of knowledge" and that situates such diversities as a sine qua non for the legitimate judicialization of interpretive authority in any legal order, but especially in the international realm. To accomplish this, the argument first reminds readers of the central problem of representation within an interstate conception of international human rights law that was first identified and grappled with by Hersch Lauterpacht as the dust of the Second World War was settling how to justify granting the power of judgment (whatever its formal force) to an international human rights body in light of objections that such judgment represents an unjustifiable imposition from 'outside' a state and its society. The Lauterpacht concern with the representation of states on international bodies is then complemented by a perspective that draws lightly on the theories of process and authority of Myres McDougal and Harold Lasswell and on notions of counterfactual assent such as are associated with the communicative theorizing of Jürgen Habermas. It is
\end{abstract}


argued that the central question of representation in evolving international human rights law should be one that leaves behind the implicit image of an international body as a surrogate for interstate deliberation. Instead, an approach is needed that locates the persuasive authority of international human rights bodies in a double conception of what is termed rhetorical responsibility: at one level, international human rights adjudication as a kind of microcosm of transnational dialogues over human rights in which, alongside representational concerns tied to political geography, non-state representational diversity is valued and given shape by purposive accounts of the point(s) of the international human rights enterprise; and, at another level, of international human rights adjudication as an enterprise that cannot ultimately be divorced from personal ethos and existential decision on the part of judges or analogous decision-makers. In a brief and deliberately tentative concluding section, it is hypothesized that the extent to which a (both) transnationalized and personalized idea of international human rights judging -- animated by an ideal of dialogical universalism can overcome legitimacy concerns based on societal sovereignty in a stillstate-ordered world can only be understood alongside an account of two key framing variables. The first variable is the nature and degree of the formal power of an international body to bind states and other actors to its judgments. The second variable is the extent to which a body can plausibly present itself as playing a 'constitutional' role vis-à-vis the community of actors to whom its judgments are addressed.

Keywords: International, human rights, law, representation, diversity, interpretation, rhetoric, dialogue, habitus, dialogical, universalism, responsibility, authority, knowledge, transnational, community, constitution, adjudication, deliberation, interactive

JEL classification: K33, K39

Author Contact: Professor Craig M. Scott

Director, Nathanson Centre for Transnational Human Rights, Crime and Security

Osgoode Hall Law School, York University 4700 Keele St, Toronto, Ontario M3J 1P3, Canada cscott@osgoode.yorku.ca 



\title{
DIVERSE PERSUASION(S): FROM RHETORIC TO REPRESENTATION (AND BACK AGAIN TO RHETORIC) IN INTERNATIONAL HUMAN RIGHTS INTERPRETATION ${ }^{C}$
}

\author{
Craig Scott ${ }^{*}$
}

\section{INTRODUCTION}

This article proceeds from a way of thinking about legal reasoning that has been aptly described as "the other of philosophy," namely, the rhetorical tradition. ${ }^{1}$ Within law as a rhetorical enterprise, the underlying purpose is the persuasion of a given audience or interpretive community that an interpretation or application of the law is just, legally correct, or meets whatever other standard is meaningful for achieving implied or actual - or, as will be discussed in Part 5 of this article, perhaps only constructed assent from that group of people. ${ }^{2}$ Legal reasoning is about the giving of

\footnotetext{
(0) 2001-2008. This work was originally written in 2001 as a commissioned piece for an edited book. By 2006, the book had entered its final editorial stage, but, due to the nature of contributions from other authors, had quite radically changed the overall thematic and subject-matter direction. Although the present article was intended by that book's editor to continue as the book's capstone chapter because its intellectual framework was felt to have significance for fields of international law beyond international human rights law 'proper', the author came to the conclusion that the book's subject-matter was too far removed and reluctantly withdrew the piece from the book with the consent of the editor. The present version essentially represents a 2002 edit, along with some updating in 2006. Before submission for publication as an article, some deepening of the final section - in light of new literature published since 2001 that is relevant to the general observations made in that section - is expected.

* Professor of Law, Osgoode Hall Law School of York University, Toronto; Director, Nathanson Centre on Transnational Human Rights, Crime and Security. The author would like to thank the Social Sciences and Humanities Research Council of Canada for its generous financial support, and Nuri Frame for his ever-able research assistance. Comments are welcome to cscott@osgoode.yorku.ca.

${ }^{1}$ Peter Goodrich, Legal Discourse: Studies in Linguistics, Rhetoric and Legal Analysis 107 (1987).
}

${ }^{2}$ See Jennifer Nedelsky \& Craig Scott, Constitutional Dialogue, in, Social Justice and the Constitution (Joel Bakan \& David Schneiderman, eds., 1992). Note that even in the field 
reasons, about choice of values in contexts of uncertainty and of a multiplicity of relevant principles, about the persuasive force of mutually supportive justificatory arguments arranged as a coherent whole. And, as I hope to show, the most desirable conception of rhetoric - in law at least is not as a unidirectional phenomenon. Least of all should rhetoric be conceptualized as an instrumental practice that sees an author of a juridical act or legal text treating her audience in effect as an obstacle to be overcome by such methods as determining what that person or group 'wants or needs to hear' so that authorship becomes in significant part a matter of encoding a message in such a way that the audience responds more viscerally than reflectively in accepting the import of the message. Rather, once questions of political legitimacy and personal ethics push matters beyond a linguistic sociology of legal reasoning into the realm of political and moral desirability, rhetoric must justify its existence. Thus it is that a grand premise of this article is that the rhetorical enterprise must situate itself within a paradigm of dialogic communication in which mutual persuasion is the orientation to argument and the quest for intersubjective validation of claimed premises, lines of argument, and conclusions is the purposive mode. ${ }^{3}$

most associated with inductive and deductive reason, science, Kuhn has demonstrated that the scientific method proceeds by persuasion within the assumptions and parameters set by paradigms (often employing logical and empirical forms of reasoning the validity of which depends on the premises from which they proceed) and also across adherents of different paradigms. See Thomas Kuhn, The Structure of Scientific Revolutions, (3d ed., 1996).

${ }^{3}$ I do not intend, at least in this essay, to establish the pedigree of the notion of law as rhetoric, except to say that there are several strands of public international law that emphasize the argumentative, judgmental, communicative, or rhetorical nature of international law. Those who are self-consciously rhetorical would include Ilmar Tammelo, The Law of Nations and the Rhetorical Tradition of Legal Reasoning Indian Y.B. Int'l L., 227 (1964); Lyndell Prott, The Latent Power of Culture and the International Judge (1979); Friedrich Kratochwil, Rules, Norms and Decisions: On the Conditions of Practical and Legal Reasoning in International Relations and Domestic Affairs (1989); and Ian Johnstone, Treaty Interpretation: The Authority of Interpretive Communities, 12 Mich. J. Int'l L. 371 (1991). Another thinker whose work I feel falls somewhere within the rhetorical tradition would be Oscar Schachter by virtue of his emphasis on normative multiplicity, law as a practice of justificatory argument, and the (in)validating roles of communities of judgment: see, e.g., Oscar Schachter, The Invisible College of International Lawyers 72 Nw. U. L. Rev. 217 (1977); Oscar Schachter, International Law in Theory and Practice (1991). Note also the emphasis in Myres McDougal, Harold Lasswell \& James Miller, The Interpretation of Agreements and 
The specific goal of this article is to move from such a general alignment with the notion of law as a field of rhetoric to an account of how such a conception can be a useful way of thinking about both the nature of (human) rights and the interpretive processes of meaning-giving that go on within the UN and other human rights treaty orders. Once these accounts are set out, in Part 2 and Part 3 respectively, I then seek to develop in Part 4 an account of representational diversity that situates it as a sine qua non for the legitimate judicialization of interpretive authority in any legal order, but especially in the international realm. To approach the question of representation in our times, I will first remind readers of the central problem of representation within an interstate conception of international human rights law that was identified and grappled with by no less a scholar than Hersch Lauterpacht just over a half-century ago - how to justify granting the power of judgment (whatever its formal force) to an international human rights body in light of the mix of principled and emotive objections that such judgment represents an imposition from 'outside' a state and its society.

Having done this in Part 4, I then juxtapose to the Lauterpachtian concern with the representation of states on international bodies, a perspective in Part 5 that draws on the work of Myres McDougal and Harold Lasswell. I will suggest that the central question of representation in evolving international human rights law should be one that leaves behind the implicit image of an international body as a surrogate for interstate deliberation. Instead, we must substitute an approach that locates the persuasive authority of international human rights bodies in a conception of international human rights adjudication as a kind of microcosm of transnational dialogues over human rights in which, alongside representational concerns tied to political geography, non-state representational diversity is valued and given shape by purposive accounts of the point(s) of the international human rights enterprise.

Part 6 is a brief and deliberately tentative concluding section. I suggest that the extent to which transnationally conceived international human

World Public Order: Principles of Content and Procedure (1967) on the communicative nature of international law and the centrality of intersubjective consensus in interpreting international law. 
rights judging can overcome legitimacy concerns based on societal sovereignty in a still-state-ordered world can only be understood alongside an account of two key framing variables. The first variable is the nature and degree of the formal power of an international body to bind states and other actors to its judgments. The second variable is the extent to which a body can plausibly present itself as playing a 'constitutional' role vis-à-vis the community of actors to whom its judgments are addressed.

\section{RIGHTS AS RHETORICAL REASONS}

\section{A. A Narrative-Analytical Account Of The Nature Of RIGHTS}

I begin with a kind of narrative of Joseph Raz's analytical account of the nature of rights in which he offers a definition and elaborates various features and reformulations of that definition. ${ }^{4}$ While perhaps not attracting general acceptance, ${ }^{5}$ Raz's analysis is persuasive in my opinion in that it captures salient formal features of the actual invocation of rights in moral and political practical reasoning. ${ }^{6}$ Here I am assuming that a clear

4 Joseph Raz, On the Nature of Rights, 93 Mind 194 (1984) [hereinafter Raz, On the Nature]. See also Joseph Raz, The Nature of Rights in his The Morality of Freedom 165 (1986) [hereinafter, Raz, Morality]. The latter is largely identical to the article except for an added treatment of Ronald Dworkin's notion of rights as trumps at 186-192. See Ronald Dworkin, Taking Rights Seriously (2d prtg.1978), corrected, with appendix, esp. 90-94, 364,. For an earlier article by Raz which takes issue with various features of Dworkin's account of rights, see Joseph Raz, Professor Dworkin's Theory of Rights, 26 Political Studies 123 (1978). For Dworkin's reply, see Ronald Dworkin, Appendix: A Reply to Critics in Taking Rights Seriously, id. 290, 364-368 [hereinafter, Dworkin, A Reply].

${ }^{5}$ See, e.g.Michael Perry, Morality, Politics and Law: A Bicentennial Essay 308 (1988).

${ }^{6}$ Raz's enterprise is to focus on the form of rights claims that he feels straddles otherwise antagonistic substantive theories:

A successful philosophical definition of rights illuminates a tradition of political and moral discourse in which different theories offer incompatible views as to what rights there are and why. The definition may advance the case of one such theory but if successful it explains and illuminates all. 
analytical rendering of the formal nature of rights claims can be a useful exercise in helping us understand the way rights seem to operate in a variety of social or linguistic contexts. Furthermore, Raz's approach has influenced my thinking for well over a decade, ${ }^{7}$ and therefore I feel virtually compelled to start my own account of rights with his.

Raz's basic definition of the existence of a right is in the following form: " ' $\mathrm{x}$ has a right' if and only if $\mathrm{x}$ can have rights, and, other things being equal, an aspect of x's well-being (his interest) is a sufficient reason for holding some other person(s) to be under a duty." $8 \mathrm{He}$ also puts this somewhat more descriptively in terms of the "fundamental role of rights in practical reasoning as representing concern for the interest of the rightholder to hold another subject to a duty." 9 Raz goes on to say that rights not only ground duties, but also other rights, the relationship between the core rights and its derivatives being "a justificatory one" as opposed to a relationship of logical entailment. ${ }^{10} \mathrm{He}$ continues:

A right is based on the interest which figures essentially in the justification of the statement that the right exists. The interest relates directly to the

Raz, On the Nature, supra note 4 at 195. Compare to Dworkin's approach in asking what the 'point' of an account of rights is, as opposed to whether the account is 'right' or 'wrong', and thus giving an account that is in some sense a 'stipulation'. While he contrasts this method to Raz's alleged penchant for theorizing about rights in terms of seeking an "empirical discovery [through] captur[ing] ordinary language exactly or completely", it would seem to me that the work by Raz focused on here does not have such strong aspirations and would not deny its own stipulative features. See Dworkin, A Reply, supra note 4 at 366.

${ }^{7}$ Admittedly in ways that Raz is not responsible for and almost certainly in ways that he might very much regret or at least not recognize as having much to do with his own views.

${ }^{8}$ Raz, On the Nature, supra note 4 at 195.

${ }^{9}$ Raz, Morality, supra note 4 at 188 .

${ }^{10} \mathrm{Raz}$, On the Nature, supra note 4 at 197, adding:

The statement that the derivative right exists must be a conclusion of a sound argument (non-redundantly) including a statement entailing the existence of the core right. 
core right and indirectly to its derivatives. The relation of core and derivative rights is not that of entailment, but of the order of justification. ${ }^{11}$

Raz's conception of rights is intimately connected to an account of their actual functioning in practical discourse: how it is that they are invoked in real-world-language encounters (granting that this real world includes the ruminations of other rights theorists). According to this view of rights as social practice, rights are something that we justify through a process of reason-giving, as structured by argumentative conventions and practices. In perhaps the key passage in the original article by Raz, he explains how rights function linguistically to help make conversation possible, especially over controversial values: ${ }^{12}$

[T] he interests are part of the justification of the rights which are part of the justification of the duties. Rights are intermediate conclusions in arguments from ultimate values to duties. They are, so to speak, points in the argument where many considerations intersect and where their results are summarized to be used with additional premises when need be. Such intermediate conclusions are used and referred to as if they are themselves complete reasons. The fact that practical arguments proceed through the mediation of intermediate stages so that not every time a practical question arises does one refer to ultimate values for an answer is of crucial importance in making social life possible, not only because they save time and tediousness, but primarily because they enable a common culture to be formed round shared intermediate conclusions, in spite of a great degree of haziness and disagreement concerning ultimate values. ${ }^{13}$

\footnotetext{
${ }^{11}$ Id. at 198.

${ }^{12}$ Note that in the account that follows I am deliberately using a narrative technique of italicizing so as to draw the reader's attention to those features of Raz's account that tie into the understanding of rights for which I hope to make a case, namely, the notion of rights as rhetorical seats of argument and the associated notion of rights as sites of dialogue.

${ }^{13}$ Id. at 208 (emphasis added).
} 
From this extended passage, we see that we argue from interests and values to rights, and from there to duties. So, to paraphrase, in any given argument that involves rights, we argue both about rights and from rights. Rights are "intermediate conclusions" or "points in [an] argument" even if rights are nonetheless often invoked in knowing irony, "as if" they were "complete reasons." Raz's implication seems to be that they do not actually function in this way (that is, as complete reasons).

We might think of this notion of the completeness of reasons in terms of looking backward and then forward from the right in question. Looking backward, so to speak, from a right, we see that a right is not complete in the sense of somehow being the beginning of a claim, or, put in the most essentialist way, of being a separate feature of the linguistic world. Even more significantly, the right is not a complete reason in the sense of its normative worth being independent of the background interests and values that generate it. Raz's approach to rights is to locate them in terms of the service they perform as linguistic labels for sufficiently important interests. Sufficiency will vary with the context, whether we are talking about 'ultimate' moral and political importance for candidates for entrenchment in human rights treaties and constitutional bills of rights or functional importance within the presuppositions of a specific area of statutory regulation. However important or weighty the interest, he emphasizes that the right thereby generated has no greater weight or importance than the background interest. ${ }^{14}$ The 'right' is a linguistic resting point, no less important for being that but no more important either.

${ }^{14}$ Rights do not "have force over and above the interests they serve. . . . In fact rights should have precisely the force which the interest has." Raz, Morality, supra note 4 at 262. Raz contends that the misperception (in his view) of those who wish to speak of rights as having acquired greater status for being rights is based on confusing the rights with the special force given to a rights claim by virtue of an authoritative institutional decision (e.g. by a court or legislature) on what is required by the right - where that decision creates a reason to act on the obligee as long as the decision-maker is generally legitimate and even if the obligee feels that the decision in the particular case is 'wrong', id.

I would add that one other reason that rights (human rights at least) are seen and used as if they have more importance than the interests underlying them is the widespread associations of rights with notions of natural law and rights and of more or less Platonic conceptions of rights as being 'out there' in a moral universe. 
Looking forward from the right, the above-quoted passage suggests that saying 'I have a right' does not do away with the need to show why, how, and subject to what conditions that right places obligations on others. There are "additional premises" that come into play in the argument from the underlying interest to a duty (whether abstract or concrete). This is so even if the speaker, in making the assertion, quite evidently (and, I might add, quite consistently) believes that the existence of the right is sufficient to ground the duty of (an)others to act or refrain from acting. Raz points out that we argue (forward) from rights, as "intermediate conclusions", to duties which then go on to function as "requirement[s] for action." 15 Just as rights are not the start of the argument, nor are they the end of the argument.

This sense that argument only ends when the obligation is justified suggests a notion of the fluidity of rights in their 'location' between interests and duties. ${ }^{16}$ Until such an obligation is argued for, the right's 'existence', as well as its implications for duty-required action, is a matter for argument. Of course, to the extent that we make our lives easier by speaking with rights - and, thus, not referring explicitly to generative interests, on the one hand, or generated obligations, on the other hand - we may not think of ourselves as speaking through rights. These kinds of rights-based conversations are, however, likely to be in areas of deeply, or, perhaps simply widely, shared understandings or, if the rights conversation involves seriously contentious issues, within narrowly circumscribed communities of conversation in which those participating are substantially like-minded on those issues. Thus, the invocation of rights not as "points in [an] argument" but as self-standing and complete assertions is a double

\footnotetext{
${ }^{15}$ Id. at, 297.

16 And, I might add tangentially at this point, between persons (including between one person and society as a whole). Raz's conception of rights as intermediate conclusions in arguments from interests of some persons to duties on others strikes me as doing justice to both the analytical and the metaphorical claim that rights should be understood in terms of relationships. See notably Elizabeth Kiss, MARX AND RIGHTS: A CONTRIBUTION TOWARDS THE DEFENCE OF RIGHTS AS INSTRUMENTS, (1989) (D. Phil. Thesis, University of Oxford) (for a primarily analytical account of rights as relationships) and Jennifer Nedelsky, Reconceiving Rights as Relationships I:1 Rev. Const. Stud. 1 (1993) (for a primarily metaphorical account).
} 
function of a context of obviousness to the invoker and the likemindedness of the audience addressed. ${ }^{17}$

So, people may and do invoke rights as complete or dispositive reasons because they believe in the merits of their claim (that their interests are sufficient to ground obligations in others). In many moral and legal traditions, people rarely invoke rights ironically, that is, to use Raz's words, "as if" they were complete reasons. When looked at more broadly from the perspective of the overall social practice of rights invocation as contrasted to the first-person perspective of the claimant, however, any dispositive effect can only occur at the end of further arguments about which duties are justified. Consistently with this, Raz speaks of the duties generated in rights argumentation as having dispositive effect, not the rights. On Raz's understanding, "[d]uties are special in the role they assume in practical reasoning. Their role cannot be captured by the usual weighing metaphor which applies to the evaluation of ordinary reasons. The[y] have pre-emptive force." 18 Later, he points out that "rights have special force" only because they are grounds for duties "which are peremptory reasons for action". 19

It is important at this juncture that some further aspects of Raz's framework understanding of rights be noted to make the preceding clear, especially since Raz displays some ambiguity on the issue of how directly

17 Rights as self-evident claims is parasitic on a particular legal, social and general linguistic context, including in an adjudicative context that relies on existing case law on what interests have been accepted to underlie rights and what obligations have been found when this right has been invoked in the past.

${ }^{18}$ Raz, Morality, supra note 4 at 186 . Raz links the pre-emptive force of duties to the role of legitimate authorities in issuing decisions translating rights into obligations which the addressee is bound to carry out. He defines "pre-emptive" in terms of "replac[ing] rather than compet[ing] with (some of) the other reasons which apply in the circumstances."

${ }^{19}$ Id. at 249. Thus, a concern I would express about Dworkin's choice of the metaphor of rights as trumps. To this point, it would at best be justified to speak of duties as trumps. Note, however, the further caveat implicit in Part 6, infra, where I suggest that we still need to de-trumpify even duties by circumscribing either-or accounts of authority and by importing insights from research which shows the inevitable to-and-fro nature of the remedial process in judicial or quasi-judicial rights review. 
a right is a ground for a duty. ${ }^{20} \mathrm{He}$ advances a notion of 'right' which suggests that, in practical thought and usage, we speak of the 'existence' of general or core rights even if we do not know in advance what derivative rights 'exist' in concrete cases or what obligations will be generated by the core right (or a derivative right, once justified) in concrete cases. In other words, Raz takes the view that a right 'exists' if we know (from some chronologically prior or simply assumed set of arguments) that it represents interests sufficiently weighty to justify holding some other societal actor under an obligation or obligations at least some of the time. If conflicting considerations are (at least in the state of current knowledge, societal beliefs, morals and so on) always weighty enough to defeat the argument about the contended-for core or derivative right, then the right does not exist at all. ${ }^{21}$ On this understanding of rights, some rights are very heavy, while others are very light; some rights are fundamental, others close to trivial.

So, we can say within this framework that the meanings of rights is almost always underdetermined and inchoate. They 'sit' there in a text or popular consciousness or a discursive field ready to be used as a source of argument in future concrete contexts. For Raz, part of this inchoateness of rights involves their capacity to generate multiple obligations even on the same facts, so that, for instance, a right might require abstention from other citizens and positive action from the government. ${ }^{22}$ But perhaps the

${ }^{20}$ This ambiguity is displayed when one sees that Raz elsewhere says, in the concluding last paragraph of the chapter in The Morality of Freedom:

According to our account the special features of rights are their source in individual interest and their peremptory force, expressed in the fact they are sufficient to hold people to be bound by duties.

Id. at 192 (emphasis added).

${ }^{21}$ Id. at 211-12. For example, most would say that no circumstances exist in Canada in which a constitutional right to own a submachine gun would be recognized by the courts, whereas, in the constitutional context of another country (that south of the Canadian border), a significant percentage of the population and judiciary might well say the right exists even if its scope and acceptable limitations are subject to further debate.

${ }^{22}$ Id. at 210: "Just as rights may impose duties on some persons and not on others, so they can impose a duty to do certain things but not others. . .." Raz, Morality, supra note 4 at 209-10: "[E]ven if a person has a right, not everyone is necessarily under an obligation to do whatever will promote the interest on which it is based." 
most interesting implication of Raz's approach is that rights are constantly resonating into the future. As Michael Perry has evocatively put it, one way to view at least some constitutional bills of rights is as akin to "sacred texts" that "constantly disturb - . . . serve[] a prophetic function in - the life of the community." ${ }^{23}$ Raz makes a similar point by linking a notion of unknowability to the dynamism of the obligations that rights ground:

A right of one person is not a duty on another. It is the ground of a duty, a ground which, if not counteracted by conflicting considerations, justifies holding that person to have the duty. . . . [T] here is no closed list of duties. . . . This dynamic aspect of rights, their ability to create new duties, is fundamental to any understanding of their nature and function in practical thought ....24

[T] he implications of a right, such as the right to education, and the duties it grounds depend on additional premises and these cannot in principle be wholly determined in advance. . . . Because of this rights can be ascribed a dynamic character. They are not merely the grounds of existing duties. With changing circumstances they can generate new duties. ${ }^{25}$

In summary, within the Razian framework, we have, I would contend, a rich notion of rights as concepts which have an active function in practical discourse as opposed to rights simply as labels for static interests. We have also a notion of rights as ways of arguing from interests and ultimate values to obligations on others in concrete social circumstances: rights make no sense outside discursive communities and outside contexts in which we can carry on a conversation about what rights we and anyone among us have and what responsibilities are therefore owed by some amongst us to others amongst - or adjacent to - us. Finally, we have a sense of rights as functional in a particular form of practical activity

${ }^{23}$ Perry, supra note 5 at 147 . It should be made clear that Raz is not talking about such fundamental rights only, but much of his discussion is clearly influenced by this context.

${ }^{24}$ Raz, Morality, supra note 4 at 199 (emphasis added)

${ }^{25}$ Id. at 212 (emphasis added). 
known as 'judging', whatever institutional form such judging might be connected to:

[I]f an individual has a right, then a certain aspect of his wellbeing is a reason for holding others to be under a duty. I used this phrase advisedly to preserve the ambiguity between saying that rights are a reason for judging a person to have a duty, and saying that they are reasons for imposing duties on him. They are in fact reasons of both kinds, but primarily of the first. ${ }^{26}$

Latent within this contrast between imposition and judgment seems to be a notion that the primary function of rights is one of persuading - that rights-based reasons make sense and are meaningful to the person on whom the obligation is found to rest - rather than of serving as a vehicle for one actor to bind another actor to the former's unilateral dictates. This observation leads us to a more explicit discussion of rights as rhetorical locations.

\section{B. OVERLAPPING UNDERSTANDINGS OF RIGHTS: POINTS IN AN ARGUMENT AND RHETORICAL REASONS}

The purpose of this present section is to relate Raz's account of rights in argument to the tradition of rhetoric, discussed briefly in the introduction, according to which legal reasoning (no less than moral or political reasoning or, for that matter, even scientific reasoning) is best seen, inter alia, as a process of reason-giving in a world in which value-laden judgment is not derivable from a monistic source, but is rather a subject of constant contestation in a world of diverse and incommensurable goods and value systems. Classical and 'new' rhetorical traditions emphasize several key notions. ${ }^{27}$ Among these are the notions of topoi and inventio.

\footnotetext{
${ }^{26}$ Id. at 200 .

27 Amongst the classics are Cicero, Topica, (H. M. Hubbell trans., Harvard University Press 1960) and Aristotle, Rhetoric and Topica, (E. S. Forster trans., Harvard University Press 1966). On the 'New Rhetoric', see Chaim Perelman and Lucie Olbrechts-Tyteca, The New Rhetoric: A Treatise on ARGUMENTATION (1969). And, accessible, albeit condensed, versions of Perelman's vast work, see Chaim Perelman, The New Rhetoric
} 
The former term, topoi, refers to 'seats of argument' - premises that "provide appropriate starting points for the discussion of a problem with which the actors or judges are confronted." 28 The latter term, inventio, refers to the process of "finding the right premises" 29 or, in other words, the process of settling on the specific topoi from which argument can then proceed within a particular interpretive enterprise.

Human rights arguments often employ rights simultaneously as rubrics for a process of inventio and as topoi. In challenging a particular action or state of affairs (let us take, for instance, the chronic underfunding of shelters that protect women from domestic violence), arguments both assume that the existence of the right needs to be argued for and assume the independent existence of the right in arguing the implications of its existence. Sometimes the two seemingly contradictory assumptions coexist in one argumentative web, while sometimes the formal legal framework helpfully specifies their analytical separation. This point can perhaps be illustrated by way of the example of the normative structure of some rights in treaties like the International Covenant on Civil and Political Rights (ICCPR) and the European Convention on Human Rights (ECHR), which attach explicit limitations clauses to some rights, and of all the rights in the International Covenant on Economic, Social and Cultural Rights (ICESCR), which treaty contains a generally applicable limitations clause. To use the ICESCR as our reference point, its Article 4 reads:

and the Humanities: Essays on Rhetoric and its Applications (1979) [hereinafter Perelman, The New Rhetoric and the Humanities]; Chaim Perelman, The Realm of Rhetoric (1982); and Chaim Perelman, Justice, Law and Argument (1980). It is worth noting the consanguinity of philosophies of practical reason and theories of argument with the rhetorical tradition, although such philosophies are almost never self-consciously in the rhetorical tradition. See for instance a work that has shaped much of my own understanding of the rhetorical dimensions of reasoning, Stephen Toulmin, The Uses of Argument (1964). Also, of perhaps more than anecdotal interest is the enthusiastic foreword by written by HLA Hart for Justice, Law and Argument, id.. In terms of intellectual consanguinity, note also the proximity in time amongst Hart's The Concept of Law (1961), THE Uses of Argument, and the original French version of The New Rhetoric (1958).

${ }^{28}$ See Kratochwil, supra note 3 at 41 . The 'seats of argument' metaphor is Cicero's.

${ }^{29}$ Id. 
The States Parties to the present Covenant recognize that, in the enjoyment of those rights provided by the State in conformity with the present Covenant, the State may subject such rights only to such limitations as are determined by law only in so far as this may be compatible with the nature of these rights and solely for the purpose of promoting the general welfare in a democratic society.

A right in the ICESCR, such as Article 12's right to the highest attainable standard of physical and mental health, could be said to function in terms of inventio at the definitional stage of argument. For example, is there 'in' Article 12 - standing alone or read in light of Articles 2(2) and 3 on the equality rights of women - a core or derivative right to adequate support services for battered women generated by their health interests? In this process, we usually argue about the right in terms of whether a concrete right can be derived (in Raz's sense of derivation) from an abstract textual provision such as the "right to health." We argue from underlying interests and broad systemic values that we feel are projected by (or immanent in) the document (for example, "the inherent dignity of the human person" mentioned in the ICESCR's preamble and the "democratic society" referenced in Article 4) and engage in some kind of teleological analysis of the right in question. At this point, the right (or, more accurately, the interpreted understanding of its scope) stands as an "intermediate conclusion" or "point in the argument", to use Raz's terms, in an argument that is not yet finished.

The right itself then goes on to function independently as a place of argument, or topos, in the justificatory debate within Article 4 (to stick with the ICESCR example) over whether any infringement of the right so defined may be justified in a "democratic society." At the end of this twostage process, we determine whether an obligation to respect, protect, or ensure the right has been breached. In this argument, we have already acknowledged and are proceeding on the assumption that a right 'exists' and, indeed, has been interfered with or infringed beyond a threshold level of acceptability, and now we wish to ask self-consciously whether such infringement is justified by "conflicting considerations", to pick up again on Raz's terminology. While it is true that the two stages can collapse into one another, due in large part to the result-oriented nature of judicial 
reasoning, ${ }^{30}$ the correspondence of Raz's analytical distinction with the manner in which the ICESCR and much of international human rights treaty law encourage this approach offers significant support for the contention that Raz has properly understood the functioning of rights in normative discourse.

The two-stage analytical distinction based on the ICESCR's structure helps us, for instance, to think of core societal understandings or wellestablished judicial interpretations of rights as operating primarily as topoi in argument within Article 4 (as well as within wider social and political discourses) - not just places of argument but commonplaces of argument. It also helps us think of claims on the periphery of such understandings and interpretations to be about rights as both inventio (the first stage of argument) and then as independent topoi (the second stage). That said, it would be naïve to think that, in practice, the inventio and topos stages of an ICESCR argument are truly isolated, especially given that there is found in Article 2(1) of the ICESCR a generic obligation on states that applies to all ICESCR rights, the duty to "take steps . . . by all appropriate means." Especially where a rights instrument places obligations of a specified actor at the centre of discourse, it will be inevitable that arguments about what the content of a concrete right is will often be phrased in terms of the specific obligations that are appropriate to place on the actor.

Let us illustrate this point narratively using the hypothetical of violence against women in the family. On the two-stage account, a process of inventio may produce consensus that violence against women in the

\footnotetext{
${ }^{30}$ I would even be willing to say 'result-initiated' in that my observations of the judicial process from the inside (as a clerk with the Supreme Court of Canada), as well as my conversations with several European Court of Human Rights judges, suggest to me that judges, especially in cases involving major value conflicts and policy implications, start with an intuitively preferred result - which admittedly can contain an implicit summary of what the judge already understands the law and her function to be - and then seek to see whether there are persuasive 'legal' reasons that sustain that result. If, in the end, the available reasons seem too unpersuasive, then a judge will (reluctantly) agree to another result. See Prott, supra note 3 , whose interviews with ICJ judges also tend to confirm this approach. More generally in terms of working with result-initiated reasoning as central to a theory of adjudication, see Duncan Kennedy, A Critique of Adjudication: fin de siècle (1997).
} 
'private' sphere is included within the harms protected against by the general right to health, but a further analysis is required in which that rights norm serves as topos (of whatever agreed weight) for deciding whether, in light of such "conflicting considerations" as the state may raise, an "appropriate means" to secure this right is for states to take steps (with whatever degree of urgency) to establish shelters to which women can flee to safety. However, once such a conclusion is reached, the obligation generated on states can easily circle back on the very specification of the right at issue, such that a core right to health that includes a right not to be subjected to family violence comes to be spoken of as including the means of securing that right by the duty-holder (i.e. the provision of shelters). In this way, a kind of reflexive spiral can be a feature of the process of first 'inventing' the right and then deciding what obligations are generated by that right while holding the right constant (as topos 'competing' with the countervailing topoi invoked as limitations on the right). If we think of the path from interests to rights to duties in terms of actual cases heard by tribunals, the progress of the spiral will depend on what is being asked for in a specific case and subsequent cases, and/or what tribunals are willing to recognize by way of obligations flowing from asserted rights. For example, we might imagine two alternative versions of a first test case. In version 1, the spiral will wind its way more slowly than in version 2. In version 1, the litigants have decided that they only want to achieve a solid first precedent that declares that the right to health includes the right not to be subjected to domestic violence and that they simply want a court to declare that such a right exists and that the state must take steps by appropriate means to secure that right; their intent is to then use such a modest victory in a subsequent case that will invoke the right not to be subjected to domestic violence in order to place a duty on the state to provide adequate shelters. In version 2, the litigants have decided to shoot higher and seek, in one case, a declaration from the court not only that there is a right not to be subjected to domestic violence but also that this generates an obligation on the state to take steps towards constructing adequate shelters. If a court agrees, it may, for example, issue a declaration to that effect and may further 'put the government to means' so as to require, at the same time as permit, the state to decide the features of a shelter program.

Let us assume that the version 2 test case then comes to stand in general discourse for recognition not just of the right not to be subjected to family 
violence but also the even more specific right to access to a protective shelter. Within some months or years, different groups look at the precedent and what has transpired since by way of state policy and legislation. Group A decides to go to court in order to build on the recognition of the right not to be subjected to family violence and not focus on specific obligation found to exist in the test case; they wish to invoke the right as the basis for a duty on the state to provide 24-hour police protection for women whose spouses are under restraining orders but who have either breached the order or threatened to do so. If they succeed, their case may come to stand for a right to police protection from threatening spouses and take its place alongside the other precedent involving the right to shelters. Group B decides to go to court and invoke not simply the abstract right to health nor the more specific right not to be protected against domestic violence but rather the even more concrete right to adequate shelters. Imagine, for example, a passage of time during which the state has established a program that meets the needs of most urban women but of few rural women. Group B's case is to argue that the right to a shelter extends to placing an obligation on the state in areas where there is less of a 'critical mass' of women and, as a corollary, higher budgetary costs associated with providing reasonable access. Meanwhile, a third group, Group C, invokes the right to battered-women's shelters not in order to seek further specification of the duty on 'the state' but to argue for an allocation of duties as amongst different state actors - e.g., in a federal system, as amongst the municipal, provincial or state, and federal levels of government. Time passes and cases on other rights (e.g. freedom of expression) have begun to argue that it is not only state actors but also 'private sector' actors that have obligations directly under the rights instrument in question, what is often referred to as the 'horizontal' application of human rights norms. Imagine that some initial judgments have accepted that corporations are bound to help secure the right to freedom of expression by making sure less powerful social groups have their views, voices, and analyses adequately represented in news delivery and programming. Group D decides to invoke the health-violence-shelter case law and go to court to argue that housing development companies have an obligation to set aside a certain percentage of planned housing space for battered-women's shelters in any new sub-division of a certain size, and to build in the costs of such shelters into the costs of the housing units. Group D may decide to cast the case as one of 'diagonality' whereby the purpose of the case is to establish that the right to shelters 
places a joint obligation on both the development companies and the local council with zoning powers. ${ }^{31}$

It is hoped that the above narrative of a hypothetical course of litigation, beginning with the right to health and moving through various stages of concretization of derivative rights and of obligations of duty-holding actors, conveys the ways in which the actual practice of rights argumentation is both consistent with the Razian analytical interests $\rightarrow$ rights $\rightarrow$ obligations path and with constant feedback processes that result in the spiralling mutation of rights as topoi and inventio. The narrative was intended to show how arguments about a right (does the right to health, and the interests underlying it, include the right not to be subjected to domestic violence?) and from a right (articulated at a certain level of generality, e.g. the right not to be subjected to domestic violence) to concrete obligations can circle back and end up operating as processes of inventio for a more concrete right (e.g. the right to adequate batteredwomen's shelters) than was initially used to generate those obligations. In this way, we arrive back at a fluid rhetorical understanding of human rights as 'spaces' within which debates about individual (and group) interests and fundamental societal values are addressed in terms of notional and actual argument over what action is (or is not) required by what actors - in the ICESCR context, primarily, if not exclusively, by states - to secure (respect, protect, and fulfil) those interests and values in concrete contexts. Such a conception and its emphasis on the argumentative construction of meaning promotes an understanding of rights which emphasizes the contingent and dynamic, as opposed to the timeless and static, nature of the rights. ${ }^{32}$

${ }^{31}$ On the notion of diagonality, see Craig Scott, Towards the Institutional Integration of the Core Human Rights Treaties, in Reaching Beyond Words: Giving Meaning to Economic, Social and Cultural Rights (Valerie Oosterveld \& Isfahan Merali eds., 2001) 7, 31-35.

32 Recall Raz on the dynamic generation of obligations through rights argumentation. A very similar idea of the dynamic and rhetorical quality of rights has been put forward by Martha Minow in the context of constitutional rights adjudication in the United States:

Legal rights . . . should be understood as the language of a continuing process rather than the fixed rules. Rights discourse reaches temporary resting points from which new claims can be made. . . . Rights in this sense are not 'trumps', but the language we use to try to persuade others to let us win this round. 


\section{Principles AND PREMises In TReaty INTERPRETATION}

\section{A. The RHetorical SchOOL Of TREATy INTERPRETATION}

Having schematically set out a case for seeing rights as possessing a special rhetorical role in normative language, I wish now to draw attention to work done several decades ago by German legal scholar Ilmar Tammelo in which he convincingly elaborates the notion of international treaty law as a rhetorical enterprise. Tammelo begins by noting various sceptical commentaries on the non-constraining nature of rules of treaty interpretation. ${ }^{33}$ His response is to argue that sceptics have approached

Martha Minow, Interpreting Rights: An Essay for Robert Cover, 96 Yale L. J. 1860, 1876 (1987).

Note, however, that the idea of 'winning this round' contains within it trumplike imagery for a concrete case. In this sense, 'dialogue' as an alternative to 'trump' is aimed more at a rights-claim as part of a process than it is aimed at the effect of having recourse to the law in a concrete case. But, even then, this returns us to Raz's notion of rights functioning "as if" they were "complete reasons" and still obscures the fact that the trumping effect only occurs as a result of an authoritative decision (as to the existence of a particular obligation that has been breached) being made at the end of a process of argument in which the right functions as a middle term that has to engage with other considerations before the obligation is produced. As well, Raz's framework specifically allows for a wide variation in the weight to be accorded rights in that second stage argument, which would also seem to be at odds with an understanding of rights as complete reasons or trumps on collective justifications.

${ }^{33}$ Tammelo, supra note 3 at 247. This includes the comment by Julius Stone, Fictional Elements in Treaty Interpretation 1 Sydney L. Rev. 344, 347 (1953-54), that the 'rules' of treaty interpretation "too often do not compel the interpretation; . . . even when they appear to do so, some competing but equally authoritative canon might, if invoked, have yielded a different interpretation; . . . in any case identical interpretations can usually be reached without invoking any set of canons at all."

Whereas Stone's inclination is to hide indeterminacy lest judicial judgment lose its authority, Tammelo responds to such instinctive recoiling in the face of rhetorical imagery (a recoiling which I call 'fluidity angst') in the following frank terms: 
rules of interpretation with the chimera of logic or stringent reasoning in mind rather than through frank acceptance that such principles are incapable of compelling results:

Thus it is appropriate to think of the principles of treaty interpretation as well as the principles guiding the choice and the application of these principles as 'places' of rhetorical argument within which the interpreter can search and find what is requisite for the application of the law. . . . [O]ne [such sceptic] has been inclined to view the rules of treaty interpretation as roads to right legal solutions rather than as footholds for struggling for these solutions . . . .34

These observations by Tammelo are borne out by a perusal of the judgments of the European Court and the way in which elements of the treaty interpretation principles of the Vienna Convention on the Law of Treaties (as well as the specific doctrines developed by the Court) have been either quite selectively or formulaically invoked. Having studied the Court's entire output until 1999, I am confident that a detailed analysis of the Court's case law would reveal numerous examples of the use by the Court of a doctrine or interpretive principle in a way which, when looked at in isolation, is inconsistent with the invocation of (or failure to invoke) that principle in another case. ${ }^{35}$ The principles of interpretation are only part of the rhetorical tool chest, and their invocation predictably enough

Where does this process of constant challenge and justification finally come to a rest? In terms of rhetoric the answer is that it never finally does so. . . . If this seems disquieting it is only because it is forgotten that insights in a changeful human world can only rest assured, and can only remain 'fresh' and viable, through constant challenge and retesting.

Ilmar Tammelo, Treaty Interpretation and Practical Reason: Towards a General Theory of Legal Interpretation (1967) 46 [hereinafter Tammelo, Treaty Interpretation].

${ }^{34}$ Tammelo, Treaty Interpretation, id. at 249-50 (emphasis added).

${ }^{35}$ Such analysis could benefit from an exhaustive comparison of the arguments that were used before the Court, as published in Series B of the Court, with the arguments that find a place in the judgment itself. Series B volumes (which have now been discontinued) contain records of the written memorials of all parties, transcripts of the oral hearings and a copy of the Opinion of the European Commission on Human Rights. 
reflects a high degree of selectivity - or 'incoherence', as some would put it. My own view is that, especially in this kind of area, interpretive principles have highly limited conceptual potential, notably because their invocation is itself largely a matter of choice. ${ }^{36}$ They are bound to be deployed as a function of a broader effort to persuade others (whomever they are deemed to be) of the justness and appropriateness of particular results. ${ }^{37}$ And we should expect no more in light of the Court's own observation in the Golder case:

36 See Colin Warbrick, Coherence and the European Court of Human Rights: The Adjudicative Background to the Soering Case 11 Mich. J. Int'l L.1073 at 1078-80 (1990), discussing cases in which the Court has reached results "without paying much attention to any constraints in the Convention text" and which are "little more than rationalizations of preferred outcomes". The tone of a kind of disillusionment is, in my view, misplaced, as judging in this context (with the breadth of rights language and interpretive principles, as well as the diversity of starting points of each judge) inevitably leads to 'rationalizations'. With respect to such diversity of starting points, see J.G. Merrills, The development of international law by the European Court of Human Rights 226 (2d ed. 1993):

[I]t is more useful to see members of the Court as caught up within a field of ideological tensions with positions ranging from extreme activism to extreme restraint on one axis, and from tough conservatism to benevolent liberalism on the other.

Furthermore, judgments should not simply be seen as a crude function of the complex relationship between a fixed matrix of each judge. This is because each judge, no less than the Court as a whole, moves about the matrix from case to case; judges are, put simply, human beings who are buffeted by 'contradictory' impulses and dispositional strains.

If the rationalizations that emerge out of such a moving matrix are unpersuasive, then it could be because the underlying reasons are unpalatable to the observer or because of the weddedness of the observer to a different range of topoi. Or, as I think is perhaps Warbrick's main concern, the rationalization is unpersuasive because it is not argued for, but rather simply asserted. In this respect, the point I make in upcoming sections is that there are better and worse methodologies based on how frankly and clearly judgments reveal all the reasoning driving a judgment - and thus open themselves to critical scrutiny of the quality of the reasoning and the over-all persuasiveness of the conclusions. Of course, being convinced of this depends on accepting a starting-point of valuing frankness, openness, and comprehensiveness in reason-giving.

37 Prott, supra note 3 . In the course of her analysis of the nature of judging in the international context, she notes (at 123) that, partly because public international law is less systematic and has more lacunae than domestic legal orders, "[t]he [International Court of Justice] judge can rely even less on purely formal reasoning within a closed system to justify his decision than can a judge in a national court". Also, she observes (at 123-24) that "[a] distinguishing attribute of non-systematic reasoning is the use of various 
In the way in which it is presented in the 'general rule' in Article 31 of the Vienna Convention [on the Law of Treaties], the process of interpretation of a treaty is a unity, a single combined operation; this rule, closely integrated, places on the same footing the various elements enumerated in the four paragraphs of the Article. ${ }^{38}$

\section{B. The Starting Point(S) Of The Vienna Convention On THE LAW OF TREATIES}

As indicated in Golder, the generally accepted point of departure for any interpretation of a treaty is Article 31 of the Vienna Convention on the Law of Treaties. Article 31(1) sets out the general (and generally accepted) rule for treaty interpretation:

A treaty shall be interpreted in good faith in accordance with the ordinary meaning to be given to the terms of the treaty in their context and in light of its object and purpose. ${ }^{39}$

Article 31(2) goes on to define the meaning of the word "context" in Article 31(1) in a limiting way so as to refer only to other textual provisions within the same treaty; "context" is thus meant to connote the

arguments of which no single one is convincing, but the cumulative effect of which is." She quotes John Wisdom's well-known metaphor of reasoning being more like constructing the legs of a chair than the links in a chain. Similarly, international judgments display a "complicated web of justification in which, in the best examples, the judge uses almost every tool which is available to him. . . . The structure of reasoning is like that of a building, not that of a chain" (at 128).

We should not think that this is somehow limited to the idiosyncrasies of the international judicial process. See Philip Bobbitt, Constitutional Fate: Theory of the Constitution (1982) for an account of how six kinds of interpretive arguments (historical, ethical, doctrinal, prudential, textual, and structural) are interwoven into different patterns with the aim of producing the most persuasive argument in a given case.

${ }^{38}$ Golder v. United Kingdom, (1975) 1 E.H.R.R. 524, 532.

${ }^{39}$ Emphasis added. 
familiar approach to legal interpretation, that is, reading one part of a text in light of the other parts and in light of the text as a whole. ${ }^{40}$ The subsequent subclauses of Article 31(3) flesh out this basic framework by reference, inter alia, to various kinds of conceptual and evidentiary reference points that may be drawn upon to understand the elements of the compendium 'rule' stated in Article 31(1): the relevance of separate agreements that evince the intention of the parties, of subsequent interpretive practice and of parallel norms of international law (notably, customary international law and general principles of international law, but also norms in other treaties to which the relevant parties - or a critical mass of the parties - are also bound) that can interpretively inform the content of treaty provisions.

The relevance of the historical understanding of treaty drafters calls for special mention. Article 32 of the Vienna Convention envisages the use of such travaux only as a supplementary method after an Article 31 operation has first been carried out. ${ }^{41}$ That noted, Article 31(4) directly refers to the

${ }^{40}$ Some have read Article 31 as a victory for the forces of semantic textualism over those of a wide-ranging contextual approach to interpretation. There is a measure of truth in this in that the particular contextualized version of treaty interpretation developed by the Yale School of International Law is almost certainly not endorsed by Article 31. However, even if Article 31(2) purports to limit the relevant context to that of the rest of the treaty text, there is ample reason to believe, judging from the actual practice of interpretation and basic philosophy of language, that no "ordinary meaning" can emerge without reference, implicit or explicit, to background or parallel social understandings that interact with the terms used in a legal document. What would seem to be rejected by the Vienna Convention approach is the New Haven view that context is nearly everything and that text is a mere point of orientation without any serious priority status in the sense of providing presumptive meaning (at least as the regulative ideal of argument) or filtering the force of other interpretive arguments.

${ }^{41}$ Article 32 of the Vienna Convention reads:

Recourse may be had to supplementary means of interpretation, including the preparatory work of the treaty and the circumstances of its conclusion, in order to confirm the meaning resulting from the application of article 31 , or to determine the meaning when the interpretation according to article 31 :

(a) leaves the meaning ambiguous or obscure; or

(b) leads to a result which is manifestly absurd or unreasonable. 
intentions of the treaty parties as an historical matter ("[a] special meaning shall be given to a term if it is established that the parties so intended"). It is not immediately obvious whether "special" is meant to convey the sense of being different or non-ordinary or, rather, the sense of a specific or limited meaning in a situation in which the term in question is otherwise open to a wider range of referents and meaning, although the first sense is probably the main intended meaning. ${ }^{42}$ How such a special meaning is to be "established" is also not specified, but it would seem sensible to have recourse to appropriate forms of historical evidence on how a term was used either in social discourse, or in legal discourse at the time a treaty was concluded. Such evidence must surely include the use of the preparatory work of the treaty itself. If so, Article 31(4) constitutes an exception in that the travaux can legitimately serve as a primary source of interpretation as long as the purpose is the focused one of proving a contended-for special meaning as opposed to using the travaux as an undifferentiated part of the overall argument about the ordinary meaning of the treaty terms. ${ }^{43}$

As noted earlier, the European Court of Human Rights took the view in the Golder case that the various elements stated in Article 31 are to be appreciated in terms of their interrelationship with each other and not as isolated elements each giving their own independent answer to the interpretive question at hand. In this way, we may think of each of the

The fact that the majority of the Court in Golder ignored the travaux in this case as being unnecessary, while in other cases of less controversy the Court has invoked the travaux shows nothing more than the obvious, that is, the mix of judicial dispositions of all the judges combined and the persuasiveness of arguments in light of those dispositions in the given case will dictate how principles of interpretation are deployed in the judgments, minority and majority.

${ }^{42}$ It is probably fruitless to keep these two senses distinct even if the Vienna Convention drafters can be shown to have meant one sense or the other.

43 If one were concerned to prevent the Article 31(4) exception from swallowing the Article 32 rule on the use of the travaux, it might be thought that the scope of Article $31(4)$ is limited to some extent by the use of the word "term" as opposed to a word like "provision" or "article". However, this avenue seems not to be viable if it is considered that the basic rule of Article 31(1) juxtaposes "treaty" with the "terms of the treaty". Thus, the word "term" appears capable of covering everything from a single word to a phrase or expression, a clause, or an entire article. 
above-emphasized phrases within Article 31(1) as constituting a starting point or, put differently (in rhetorical-tradition fashion), a non-dispositive commonplace of argument. ${ }^{44}$ In the Article 31 process, no single element of interpretation has been granted a licence to act as a pure competitor to the distinct interpretations separately arrived at under the mantle of one of the other elements. Put differently, no single school of interpretation associated with one of the elements that has found mention somewhere within Article 31 - textualists, contextualists, teleologists, historicists enjoys monological dominion. By this understanding of Article 31, the ability to put forward an interpretation based on any one school of interpretation is constrained by the requirement to have first entered into a dialogue with the other schools. In this way, interpretation is ultimately a holistic act of understanding that gathers together the combined perspectives brought to bear on the question by the different points of reference sanctified in Article 31.

However, this does not mean that the various commonplaces of argument found in Articles 31 enter into the interpretive pot without some initial allocation of priority or hierarchy in presumptive weight. For example, arguments about the intention of the parties based on historical documentation have less weight than arguments based on an evolved understanding in light of changes in background international legal principles (general or customary) since the adoption of the treaty; as already mentioned, Article 32, read in light of Article 31(1), makes clear that recourse to historical intention as manifested in the travaux is a subsidiary means of interpreting a treaty. In putting the matter more affirmatively, Judge Matscher of the European Court of Human Rights has expressed a widely held view that all interpretations are bound to keep both the text and the purpose at the centre of an interpretive account:

It is clear that the text of the treaty itself is given first priority and must be the starting point for any interpretation, and attention should be directed not so much to its semantics as to

\footnotetext{
${ }^{44}$ On these rhetorical terms, see Perelman, The New Rhetoric and the Humanities, supra note 28 and Kratochwil, supra note 3.
} 
the object and purpose of the treaty (teleological interpretation). ${ }^{45}$

This principle of purposive-but-text-sensitive interpretation applies to treaty interpretation generally and not only to international human rights treaties. In this way, text and purpose might be thought of as the central pillars upon which the construction of an argumentative structure takes place, the governing assumption being that they are to bear an equal weight and are mutually supporting. An understanding of purpose is guided by the text, while an understanding of the text is guided by the purpose: this is the most basic structure of treaty interpretation. If this may be thought of as the engineer's ideal design, it must also be acknowledged that architectural modifications and innovations are both necessary and desirable in the life of any home or community. That said, if it is proposed that one pillar should (or even must) bear more weight, then a departure from this balance needs to be carefully justified in terms of whether that pillar can sustain the proposed weight in light of all the other structural elements of the building. Have all the parties to a treaty participated in an interpretive amendment so as to make the text in question mean something entirely different, thereby replacing the original textual pillar with another? Is the historical intention so clear on the existence of a special meaning of a term that the textual pillar's strength is weakened to the extent that it must be reconstructed using the more solid historical material? Is the text so clear that arguments based on the purpose of the document cannot be accepted even though that purpose is necessarily undermined to some extent by the text-faithful reading? Is the purpose so compelling that certain features of the text that seem to contradict that purpose can be modified or even ignored, or certain received doctrinal interpretations of those terms reinterpreted? It can thus be seen that the extent to which the text or purpose may be displaced inter se or by other elements is a function of whether the overall structural form remains sound (the engineer's primary concern) and both aesthetically and functionally pleasing (the architect's primary concern).

${ }^{45}$ Franz Matscher, Methods of Interpretation of the Convention, in The European System for the Protection of Human Rights 63 (Ronald St. John Macdonald, Franz Matscher, \& Herbert Petzold eds., 1993). 
If it is true to say that the Vienna Convention provides the starting points for interpretation, it must also be said that, for all their air of comprehensiveness, the provisions of the Vienna Convention do not exhaust the field of relevant interpretive touchstones. Other sources of argument may be called in aid such as case law (including doctrines concerning the weight to be attributed to precedents), treaty commentary and general doctrine written by academic commentators, interpretive guidelines issued by international agencies particularly concerned with the subject matter of the treaty in question, references to the overall goals of international legal order (or of a specific field, such as international human rights law, law of the sea, diplomatic immunity, and so on), and the resolutions of international organizations possessing varying degrees of normative pretension and force. These sources are in turn cocooned by broader forms of argument that self-consciously draw on relevant considerations that are not strictly legal, including appeals to fundamental social values, consideration of the social consequences of one interpretation over another, theories of the appropriate role of a particular institutional interpreter as compared to other institutions, and so on. ${ }^{46} \mathrm{As}$ a matter of either the rules of evidence of tribunals, or of extra-tribunal practice, virtually no argument is formally barred by international law from playing a supporting role for other arguments of a more central character. These 'external' referents inevitably come into play given that Article 31 of the Vienna Convention "gives no directions on the questions ... of a static or historical as opposed to a dynamic or evolutive approach to interpretation, and of a narrow as opposed to a broad interpretation". 47

Such questions condition what might be thought of as the overall interpretive orientation or guiding interpretive baseline for a particular treaty. Here, it is worth noting parenthetically that the idea of a single baseline is of course a simplification that should instead be thought of as complex compendium of multiple baselines. The characterization of the subject matter or field of the treaty (what Article 31(1) refers to as its "object") will be especially instrumental in settling upon the appropriate interpretive orientation or baseline for the treaty as a whole or for a given

\footnotetext{
${ }^{46}$ See Bobbitt, supra note 37, for standard forms of argument in US constitutional law.

${ }^{47}$ As put by a former judge of the European Court of Human Rights: Matscher, supra note 45 at $65-66$.
} 
part of the treaty. A bilateral boundary treaty and a multilateral aviation convention will be viewed in starkly different terms, and in turn these will be viewed as instruments which are very different from the United Nations Charter, and so on. All participants in treaty interpretation bring to bear implicit and explicit assumptions about the nature of the field in question. This is a feature of the interpretive enterprise that is relatively unremarked upon. Indeed, it is not uncommon to witness the expression "object and purpose" in Article 31(1) collapsed into and used interchangeably with "purpose". ${ }^{48}$ However, from a linguistic point of view, the "object" of a treaty and its "purpose", although closely related, are not the same.

The object may be thought of as helping to provide a macro-context for the interpretive enterprise, including the way in which (and the detail with which) a treaty's purpose should be characterized. ${ }^{49}$ Various treaty macrocontexts may share common features which may tend to produce a core orientation for the interpretation of these treaties to the extent that the subject matter of these treaties shares relevant characteristics. For example, ship navigation and maritime traffic conventions may be thought to have significant commonalities with some aviation and air services agreements, or at least to share certain core elements. Most significantly, these kinds of treaties would seem to be paradigms of treaties, the subject matter of which is perceived as having, virtually ready made, a reciprocity of interest that - contrary to international human rights treaties - requires the interpreter to track carefully the original and evolving intersubjective expectations of all of the states party to the treaty. Yet, an object of a treaty need not be whole or pure; for example, air and sea traffic conventions may incorporate elements that deal with environmental sideeffects in the commons (for example, the air and water of the high seas) or

\footnotetext{
${ }^{48}$ See, for example, the Matscher quotation, supra text at note 45.

${ }^{49}$ Even this description of the object of a treaty retains formalist constraints, for it could be said that there are even wider "macro" contexts in which every interpretation is situated. For example, the classic "wider context" that seemed to work at virtually every level of Myres McDougal's interpretations was that of the Cold War. For reasons too numerous and detailed to elaborate here, it is not desirable to conceptualize such variables as being structural features of legal interpretation as opposed to contingently present aspects of political reality and perspectival dispositions which legal interpretation necessarily takes into account in ways too unpredictable and variable to capture in any useful way the required aspects of legal interpretation itself.
} 
shipboard safety conditions, and these elements may be thought to be less dependent on reciprocity of intention and more conducive to interpretation that independently seeks to promote the object in question. Thus, different treaty subject-matters or objects may usefully be examined in terms of the varying extent to which interstate reciprocity is the glue of the treaty either because of what may seem virtually inherent aspects of the object in itself (for example, a rules-of-the-road treaty such as an aviation treaty) or because state representatives clearly perceive reciprocity as an indispensable element of the treaty relationship. In particular, normative reciprocity and effectiveness are very often indissociable if a treaty regime provides either for no role, or for a very limited and sporadic role for authoritative third-party institutional actors to interpret treaty terms (either at the international level, or within the legal order of each state party) and thereby to play a partially constitutive role in defining the interests and expectations of states. ${ }^{50}$ Thus, the presence of institutional interpreters other than states will itself have a constitutive impact on the characterization of the nature of the subject matter.

\section{SPECIFIC APPROACHES To INTERNATIONAL HUMAN RightS TREATIES}

It is hoped that the foregoing gives an adequate idea of the largely nonhierarchical constellation of principles and premises that must or can be drawn upon in giving meaning to a treaty norm. It will now be helpful to make some schematic observations about the specific approaches to the sources of argument in human rights treaty interpretation that have developed over the past two decades. ${ }^{51}$ Perhaps the most fundamental principle, now widely accepted, is that the underlying object and the purpose of a human rights treaty - and of specific terms within any given

\footnotetext{
${ }^{50} \mathrm{See}$, in particular, the example of nuclear arms non-proliferation treaties in the leading account of international treaty interpretation in terms of the role of horizontally structured interpretive communities. See Johnstone, supra note 3.

${ }^{51}$ It is recognized that this is itself an exercise in rhetoric, akin to the normativeexplanatory method Raz draws attention to in The Morality of Freedom, supra note 4.
} 
treaty - shape textual analysis to an even greater extent than normal. ${ }^{52}$ This is due not so much to the fact that either the object or the purpose has actually been assigned greater interpretive weight as an abstract matter, but to the special nature of the object (interests which are fundamental to individual spiritual and material well-being and which are also instrumentally valuable to securing various communal goods such as pluralistic democracy, a climate of civic tolerance, and a non-arbitrary legal system) and purpose (the protection and promotion of human rights) of a human rights treaty.

In this regard, the glue of interstate reciprocity loses much of its conceptual relevance because the primary treaty relationship is generally imagined much less in terms of the horizontal relationship(s) among states (and the concomitant expectations of state officials) and far more in terms of the treaty's role in constituting a legal relationship between each state party and those individuals and groups subject to that state's jurisdiction. ${ }^{53}$ As classically phrased by a former judge of the Inter-American Court of Human Rights and member of the UN Human Rights Committee who is now a judge of the International Court of Justuce:

${ }^{52}$ Thomas Buergenthal, Advisory Practice of the Inter-American Court, 79 Am. J. Int'l L. 1 (1985) Michael Boyle, David J Harris \& Colin Warbrick, Law of the European Convention on Human Rights 5-29 (1995) Olivier Jacot-Guillarmod, Les principes d'interprétation, in La Convention européenne des droits de l'homme" commentaire article par article 41 (Louis-Edmond Pettiti, Emmanuel Decaux, \& Pierre-Henri Imbert eds., 1995).

53 That is not to say that this represents all of its relevance: see René Provost, International Human Rights and Humanitarian Law (2002). That being said, in human rights treaties, it seems most accurate to say that reciprocity metamorphoses into a question of fair treatment of each state party by any third-party institutional actor charged with interpreting a treaty. Reciprocity will continue to function as a motivational factor and a factor conducing to compliance when states perceive their interest to lie in promoting the protection of human rights in other states, for example if they see this as giving support to a way of life they wish to promote domestically because they believe such promotion has instrumental effects on matters such as international peace and security or because they have significant numbers of nationals who they wish to see treated well abroad (for instance migrant workers). However, interstate material reciprocity will almost never structure state obligations in the pervasive ways it does relative to other kinds of treaties. The best examples of this are in the areas of applicability to foreign nationals, of countermeasures and of reservations. 
[A human rights treaty is] a multilateral instrument or framework enabling States to make binding unilateral commitments not to violate the human rights of individuals within their jurisdiction. ${ }^{54}$

Perhaps the most authoritative statement of principle remains that of the European Court of Human Rights, which remarked in Ireland $v$. The United Kingdom that the interstate context of the litigation did nothing to change the non-reciprocal basis of each state's commitments under the European Convention on Human Rights:

Unlike international treaties of the classical kind, the Convention comprises more than mere reciprocal engagements between Contracting States. It creates over and above a network of mutual bilateral undertakings, objective obligations which in the words of the preamble benefit from a 'collective enforcement'. 55

A number of related propositions feed from and into the interpretive orientation just described. All of the following propositions are phrased as a matter of degree given that no hard-and-fast statements can hope to capture all the interpretive practice that has rapidly grown up around dozens of regional and universal human rights treaties in recent years. In particular, no attempt is made to probe the extent to which international tribunals, in the course of practical decision-making, sometimes invoke certain interpretive principles formulaically or selectively in ways that suggest that what really matters is doing justice on the facts of the case (always of course with an eye to how the precedent will look in the future) - as they appear to a group of jurists after receiving argument from the state and non-state parties and after good-faith deliberation among themselves.

The first related proposition is that the travaux are generally, although not invariably, treated by tribunals as being even less significant than the

\footnotetext{
${ }^{54}$ Buergenthal, supra note 52 at 19

${ }^{55}$ Ireland v. United Kingdom, judgment of 15 January 1978 (Series A no. 25, p. 90, S 239).
} 
travaux are for non-human rights treaties. The reason for this is precisely because the reciprocity dimension is far less important (as, accordingly, are the specific historically bound intentions of states) and because the purposive dimension (itself partly generated by the general historical intent to protect human rights) is far more significant. The practice is that international human rights tribunals make use of the preparatory work "only on comparatively rare occasions". ${ }^{56}$ This does not mean that the travaux should not be referred to at all, especially if the negotiating record helps clarify the nature and strength of a particular human rights concern. It is fair to say, however, that the travaux are relied on infrequently and unpredictably in order to enhance and make more persuasive interpretations already arrived at based on text and purpose and comparatively rarely to justify an interpretation that goes against purposive reasoning. 57

By way of a second proposition, the notion of purposive interpretation has often been associated, as a matter of general international treaty interpretation, with a principle of effectiveness according to which one role of interpretation is to make effective what the parties bargained for rather than settling on a meaning that would render ineffective, in whole or in part, the treaty or provision. ${ }^{58}$ This principle of effectiveness plays an

\footnotetext{
${ }^{56}$ Matscher, supra note 45. See also Merrills, supra note 36.

${ }^{57}$ A good example is the refusal by the European Court and Commission of Human Rights to read a right to divorce into Article 12 of the European Convention on Human Rights, which guarantees the "right to marry", primarily on the basis that the travaux reveal that all states (most notably those, like Ireland, with legal prohibitions on divorce) at the time of drafting understood that such a right was specifically excluded. See Johnston v Ireland, judgment of the European Court of Human Rights, Ser. A, No. 112 (1986). The Court drew some sustenance from the fact that the final clause in the text of Article 12 also seems to mandate, or at least justify, a higher level of deference to domestic legal systems with respect to the specific subject matter of marriage. Article 12 reads: "Men and women of marriageable age have the right to marry and to found a family, according to the national laws governing the exercise of this rights." See the further discussion of Johnston in Part 6, infra.

${ }^{58}$ See e.g. D.P O'Connell, International Law for Students 108 (1971): "The parties are deemed to have intended a result that can be effectively brought about....Lauterpacht drew from his analysis of the practice of the International Court the proposition that the intention of the parties must be interpreted even to the extent of disregarding the letter of the instrument, and of reading into it something which, on the face of it, it does not
} 
even more pronounced role with respect to international human rights treaties as expressed in the not-infrequent reminder by the European Court of Human Rights to interpret human rights provisions so as to render them not "theoretical or illusory but . . practical and effective". ${ }^{59}$ It is important to note, however, that international human rights tribunals have been careful to affirm that the actual words used in a text, reflecting as they do careful choice by the drafters, must still play a constraining role with respect to how far purpose can produce broad or generous interpretations; in other words, creative and expansive readings of general language should not cross over into distorted readings, recognizing as always that one judge's illegitimate distortion may be another judge's legitimate and even necessary creative reading. ${ }^{60}$

Thirdly, the focus on purpose also tends to generate a principle of interpretation according to which interpretations of the definitional scope of rights that favour the protection of the values and interests underlying legal rights (and, in this sense, are favourable to the individual) are to be preferred over alternative interpretations that are less protective. ${ }^{61} \mathrm{~A}$ corollary is that textual exclusions from the definition of a right, as well as limitations on rights, once defined, are to be interpreted restrictively. ${ }^{62}$ This is not to deny that the interpretive terrain is still significantly opentextured, not only for identifying interests worthy of protection, but also

contain, so long as that 'something' is not 'contradicted by available and permissible evidence of the intention of the parties.' When there is an implicit collision between the principle that the intention of the parties is to prevail and the principle of treaty effectiveness, the Court, in [Lauterpacht's] opinion [adopted by O'Connell], will give emphasis to the latter."

59 Airey v. Ireland, 32 Eur. Ct. H.R. (ser. A) (1979); Artico v. Italy, judgment of 13 May 1980, Series A no. 37.

${ }^{60}$ Merrills, supra note 36 at 90 . A related point is that the judicial gloss placed upon texts through the jurisprudence constante of case law does generate its own form of textual resistance by creating presumptions against otherwise viable interpretations. While international human rights tribunals do not follow a doctrine of strict binding precedent (unknown to international law, in general), for better or worse they do approximate such a system.

${ }^{61}$ Buergenthal, supra note 52.

${ }^{62}$ Matscher, supra note 45. 
for identifying and applying considerations relevant to limitation. Such open-texturedness is especially the case in situations of rights-related polycentricity - direct conflicts between the concrete rights-protected interest(s) of one person and the concrete rights-protected interest(s) of another. Rather, the claim is more that the principle of restrictive interpretation (of limitations on rights) applies to a fuller extent when the concrete rights of specific other persons are not at stake and others' rights are diffused within a collective good to the extent that we speak of the rights of society or of the community facing those of the individual as opposed to either concrete social sectors or groups or specific individuals. Yet, even then, it would be inaccurate not to recognize that, at the international level no less than in domestic constitutional orders, the various kinds of justifications of limitations on rights (rationality, necessity, proportionality) are applied with varying degrees of stringency - as a function, inter alia, of the general importance of the rights at issue, perceptions of the legitimacy and competence of the tribunal to make its own judgments in the field of activity in question, the seriousness of the impact on the person whose rights are affected in the specific case at hand, and the pressing nature of countervailing considerations.

The fourth proposition is that the legal practice of interpreting human rights is uniquely situated at the crossroads of the social, political, moral and economic discourses with which it constantly interacts. ${ }^{63}$ As such, interpretations may evolve as understandings of human rights (in general or in particular) change and thus as the guiding purpose (again, in general or in particular) changes. Such a principle of evolutive or organic interpretation has not only been frankly acknowledged by international tribunals, but it has also been welcomed as healthy and necessary to prevent stasis, ossification and ultimately irrelevance. ${ }^{64}$ The evolution of

${ }^{63}$ This does not exhaust the spectrum.

${ }^{64}$ See especially Tyrer v. United Kingdom, judgement of 25 April 1978, Series A no. 26, pp. 15-16, para. 31, and the invocation by the European Court of Human Rights of the notion of a "living instrument." And see the reiteration of this notion much more recently, in 1995, in the following terms in Loizidou, infra note 120 para. 71 "That the Convention is a living instrument which must be interpreted in the light of present-day conditions is firmly rooted in the Court's case-law (see, inter alia, the Tyrer judgment...). Such an approach, in the Court's view, is not confined to the substantive provisions of the Convention, but also applies to those provisions, such as Articles 25 and 46, which govern the operation of the Convention's enforcement machinery. It follows that these 
social, political, moral, and economic understandings and values can, of course, include the good, the bad, and the ambiguous. Not surprisingly, the sense of evolution in interpretation endorsed in international jurisprudence is that of progressive evolution - that is to say, changing interpretations should benefit human rights protection rather than cut back on it. In this way, human rights treaty protection acts, in principle, as a ratchet. Once a certain interest or societal group has been recognized as worthy of protection in terms of human rights, stepping back from past levels of protection in the name of interpretive evolution is presumptively regressive and, as such, unjustified.

Of course, as many questions are begged by the above formulation of the fourth proposition as are answered by it. It does not and cannot on its own provide a basis for determining when (or even whether) new life has to be breathed into a right, that is, whether or when evolutions in values and understandings parallel to the treaty order are ripe to be incorporated into that order. More significantly, this formulation is apt to be taken as a naïve suggestion that progress with respect to rights protection is a straightforward quantitative question of cumulatively greater protection of the underlying interest: the more protection, the better. In fact, there is a pervasive qualitative dimension in that what may look to be regressive in one dimension (less protection for one interest) is actually progressive in another (more protection for other interests). In particular, evolutions in understandings bring with them a constant reappreciation of how the rights of different persons (or groups) should interact in terms of relative priority and in terms of a necessary mutual accommodation. As such, the maximization of human rights cannot be the kernel of the idea of progress; rather, the governing injunction must be that of the optimization of human rights. ${ }^{65}$ Only a few examples need to be given to illustrate the point. Defence rights of accused persons that have included the right to dredge up the sexual history of a rape victim may come into conflict with new understandings of gender equality. Parents' rights to have their children educated in terms of their philosophical or religious convictions may yield

provisions cannot be interpreted solely in accordance with the intentions of their authors as expressed more than forty years ago."

${ }^{65}$ See John Rawls, Political Liberalism 331-40 (1993), on the idea of trade-offs among rights and the goal of the optimal as opposed to the maximal protection of all rights. 
with time to greater recognition of children as rights-holders whose choices and (state-protected) best interests must now be given more weight than they have been given in the past. The right of landlords to some degree of property protection must be reevaluated in the face of social policies designed to assist disadvantaged tenant groups, especially when there is a parallel recognition of the right to adequate housing as a core human right. The right to freedom of expression may interact with equality in ways not fully appreciated in the past in regard to matters such as pornography and hate literature, while limitations on pornography may have to be re-evaluated when the perspectives of traditionally excluded sexual minorities are integrated with gender-oppression analysis and some feminist theories. What becomes apparent from the foregoing example[S] is that the idea of progressive evolution is a regulative ideal, but not one which tells us on its own whether a rights-protected interest should receive more or less extensive protection. Yet, that said, if the ideal of progress cannot hitch its wagon to any essential truth with respect to the current level of protection of a right, it must surely have the effect of requiring a government putting forward an argument that would cut back on that level of protection to bear the burden of making an affirmative case as to why the new interpretation is desirable, perhaps even necessary, for progress. In such an exercise, the more directly the government can connect the lessening of protection of one right to an evolving (or newly understood) necessity to protect another right either of identifiable persons, or of an identifiable social group, the more likely that the case can be made out that it is necessary to accord the right less protection than the right has been accorded in the past. Similarly, the more remote the connection to the recognized rights of others (or, put differently, the more the rights of others become indistinguishable from arguments about the good of society as a whole), the more exacting must be the scrutiny as to whether it is indeed justifiable to lower the protection.

\section{Chronic Vagueness, Disagreement And Human Agency}

There is an additional formal quality of fundamental human rights interpretation generated by a constitutive feature of the field (i.e. the object of treaty interpretation): human rights tend to remain chronically vague concepts even after centuries of case law. Such vagueness is not just - 
indeed, not primarily - a function of the generality of their phrasing but also a function of the received meanings accorded to textualized rights being forever 'vulnerable' to evolving understandings of both their own contours and their relationship to the "conflicting considerations" spoken of by Raz. This semantic vulnerability is magnified in institutional contexts lacking a system of formally binding precedent or in which the convention of according respect to a jurisprudence constante includes relatively lenient criteria for departing from precedent.

In light of this governing feature of the field, some would say that at minimum what is needed - and what can (must) be provided by the law are parameters for argument (the premises to which Raz refers), most notably in the form of principles and even detailed rules of interpretation. In this way, it is hoped that unwieldy rights can be disciplined and perhaps even rendered "coherent." 66 But the search for well-established canons of interpretation of treaties that would provide legal shape to an international human rights trbunal's interpretive endeavours is surely a chimeric one. As we have seen, principles and premises of interpretation play at most a channelling role in relation to specific interpretive contexts and associated audiences. While some interpretations can be excluded from the range of interpretations viewed as having a claim to reasonableness by a given interpreter in relation to his or her interpretive community, no uncontrovertible, determinative result is possible simply by virtue of the 'correct' employment of these principles and premises.

Thus, it is not surprising that Tammelo suggests that the real guides and boundaries of interpretation can only ultimately be provided by higher level topoi rather than by those topoi represented by interpretive principles (or those represented by rights themselves). He fastens on those of "good faith, reasonableness and prudence." Crucially, Tammelo links the role of these values (I would call them ethical dispositions or human virtues) to the necessity for the institutionalization of rhetorical argumentation as opposed to placing any faith on them as free-standing normative constraints on interpretation:

\footnotetext{
${ }^{66}$ Recall Warbrick, supra note 36 at 1073, who focuses on the lack of "coherence" of Court decisions in terms which I am inclined to speak of as problems of "persuasiveness".
} 
The best remedy that legal experience has provided [for the openness and fluidity of interpretive arguments and outcomes] is the establishment of institutions by legal orders which have the ultimate authority to lay down what in a particular case a vague term or ill-defined concept is to mean. The necessity of these institutions is suggested by the very nature of practical reason, which can operate only through human agents capable of insight, of discernment, and of making up their minds. Hence it may be said that the judicial function in legal orders is of paramount importance. And this is why the debility of this function in the international legal order is one of the main weaknesses of international law. ${ }^{67}$

So, not surprisingly, we arrive - expressing Tammelo in other terms - at the view that, in the end, situated human beings and their faculties of judgment form the major constraint in interpretation. Yet, is "constraint" the right word? Tammelo really goes no further than to endorse a decisional positivism - the necessity for there to be "authorit[ies]" to "lay down . . . mean[ings]." Short of taking refuge in some essentialistic faith in shared insight amounting to discovery of truth, a Tammelian call for the institutionalization of rhetoric is, in and of itself, but a classical call for order and finality through legal process. It does not go the next step and ask hard questions about the normative legitimacy, beyond an assumed legal validity, of given institutional arrangements for producing authoritative interpretations.

Can any observer of legal rights adjudication in the 1990s read passages such as those just quoted without almost immediately asking questions like: Whose good faith, reasonableness and prudence? Whose insight and discernment? Who has the power to persuade and who do they imagine they must persuade? To answer "human agents" is to embrace a naivety wholly out of keeping with the realism represented by the understanding that in a world of rhetorical reasoning there can be no certainty or necessary justice. Thus it is that a rhetorical approach to human rights

${ }^{67}$ Tammelo supra note 3 at 251-52. For an excellent discussion of how parties to a treaty can constitute a context of good faith and reasonableness through the interpretive community formed by intersubjectively arriving at shared meanings, even without thirdparty dispute settlement organs, see Johnstone, supra note 3. 
interpretation has a special need to link that understanding to the problems of institutional representation and the associated responsibility of those who are charged with authoritative interpretive roles. To these questions we now turn.

\section{The Ongoing Pedigree Of State SurRogacy: LAUTERPACHT AT THE HALF-CENTURY ON REPRESENTATION AND AN INTERNATIONAL HUMAN RIGHTS COURT}

Having arrived at a place where Tammelo points to the need to discipline the fluidity of rhetoric with the positivization of interpretive authority, I turn to an almost-forgotten classic in international human rights scholarship. A discussion of the attention paid by Sir Hersch Lauterpacht in his mid-century work International Law and Human Rights to the nexus between international authority and state representation is useful for understanding how the problem to be overcome is still substantially unmodified 50 years later in conventional thinking ${ }^{68}$ Writing in 1950, Lauterpacht's specific focus was on an international human rights court at a time when it was still hoped that the Universal Declaration on Human Rights would be followed by an international treaty overseen by such a court As it would of course turn out, something quite different evolved with the adoption in 1966 of the two Covenants, the ICCPR and the ICESCR. For several decades, then, it was only in Western Europe that a court was written into a human rights treaty, namely, the European Court of Human Rights. ${ }^{69}$

\footnotetext{
${ }^{68}$ H. Lauterpacht, International Law and Human Rights (Archon Books ed., 1968).

69 The American Convention on Human Rights later created another regional court, the Inter-American Court on Human Rights.
} 


\section{A. LAUTERPACHT ON JUdicial AUthority AND (INTER)STATE REPRESENTATION}

Lauterpacht starts by taking state sovereignty as a baseline premise. As such, he notes, as a corollary, that the "the jurisdiction of [a proposed International Court of Human Rights] to review . . . acts of the highest organs of the State will constitute a pronounced degree of surrender of national sovereignty." ${ }^{70}$ In attending to the problems of the legitimacy and general authority of such a court in an order organized with state sovereignty as the dominant normative baseline, he turns, inter alia, to the question of how representation on such a court could help attenuate the problem of the authority of court judgments.

Before looking at his compositional scheme, however, we must first note the form of judgment that Lauterpacht is assuming would issue from any court. ${ }^{71}$ Lauterpacht is assuming that court decisions would be both final and binding on any states subject to a negative judgment. That being said, it is significant that he did limit the remedial scope of the binding court judgments. Under his scheme, remedies were to be limited to declarations of incompatibility and, when appropriate, decrees of monetary compensation. These limited remedies were contrasted by Lauterpacht to others that he rejected as nonviable, notably, according the International Human Rights Court the remedial "power of formal nullification of acts of the highest judicial or legislative organs of the State." 72 Lauterpacht's rationale was the need to "soften" the "impact of the innovation [of international court review] . . . without detracting from its reality and effectiveness." "73 $\mathrm{He}$ felt this would be achieved by making judgments binding but of limited remedial scope.

\footnotetext{
${ }^{70}$ Lauterpacht, supra note 68 at ${ }^{383-} 8^{4}$.

${ }^{71}$ The connection between representation and form of judgment will be touched on in Part 6.

${ }^{72}$ Lauterpacht, supra note 68 at ${ }^{384 .}$

${ }^{73}$ Id. at ${ }^{384}$. Interestingly, faced with the binding power of its own judgment under the European Convention on Human Rights, the European Court of Human Rights has restrictively interpreted Article 50 of the European Convention to limit its own remedial role in exactly the way that Lauterpacht proposed; see Craig Scott, Multinational Enterprises and Emergent Jurisprudence on Violations of Economic, Social and Cultural
} 
Now that we have noted the formal powers Lauterpacht was assuming his proposed International Human Rights Court would have, we now return to the question of representation. Lauterpacht's proposed court was to have a permanent nucleus of 11 judges, to whose ranks he proposed would be added, for each case, three additional members, who would be judges and nationals of the impleaded state. He conceived of this case-by-case expansion of the Court from 11 to 14 members as a device that would "render it, in a sense, an enlarged Court of Appeal of the State." 74 Put differently, the presence of national representatives would, in this way, enhance the dimensions of self-judgment (by a state) involved in a court decision. We might think of an embedded metaphor of the Court crossing a frontier from outside (the state) to inside (the state) by being transformed metaphorically - "in a sense" - into a national court.

It is instructive, however, to record exactly how Lauterpacht conceptualized a philosophy of state representation as speaking to (while not fully resolving) the problem of authority. His reasoning remains relevant to the general problem of the authority of judgments (international or not) vis-à-vis those to whom the judgments are addressed. Lauterpacht reasoned first of all that the participation of national judges would help alleviate the sense of judgments being imposed by foreigners, especially judgments decided by narrow majority votes (for example, 6-5) of the permanent 11 judges:

These persons [that is, the national judges] would have the power of decision and voting on the same footing as the permanent members of the Court. Their participation would not decisively affect the character and continuity of the Court. On the other hand, it would ensure that decisions vitally affecting the constitution and the sovereignty of the State

Rights, in Economic, Social and Cultural Rights: A Textbook 563, $576-77$ (Asbjorn Eide, Catarina. Krause, \& Allan Rosas eds., 2d ed. 2001), for a discussion of the Court's continuing refusal (in Guerra v. Italy, judgment of 19 February 1998, European Court of Human Rights, Reports of Judgments and Decisions 1998-I, No. 64) to develop a declaratory remedial jurisdiction, let alone an injunctive one. See Part 6, infra, for a brief discussion of the negative effects of the paradigm of binding legal judgment.

${ }^{74}$ Lauterpacht, id. at ${ }^{384 .}$ 
concerned are not given by a small majority of foreign judges. ${ }^{75}$

Lauterpacht goes on to elaborate how the authority of the judgment (within the impleaded state) - by which he means its persuasive authority - would vary in proportion to the representation of the national judges in the majority decision. On this view, apart from positive legal authority (the formal bindingness of a judgment), a more general authority (perhaps better termed its "legitimacy") 76 is viewed as relative to the degree of (surrogate) representation of the state-society in the judgment or, put the other way around, the extent to which the judgment can be viewed as having been produced through an exercise of self-judgment:

[A] judgment given against the State by a decision concurred in by all the judges who are nationals of that State would be fully acceptable to its public opinion, for it would indicate that there has taken place an obvious violation of the [proposed International] Bill of Rights. If all the nationals of that State were to vote in favour of upholding the measures taken by it, an adverse decision would be made correspondingly difficult, while an unfavourable decision given by a majority including one or more nationals of that State would not be open to the objection that it is a judgment of a purely foreign tribunal and would to that extent be more acceptable to public opinion. ${ }^{77}$

Of considerable interest in the immediately preceding passage is the fact that Lauterpacht is oblique in addressing the situation in which all three national judges vote for finding no violation. He says only that "an adverse decision would be made correspondingly difficult." This could be a purely empirical statement of likelihood in the sense that a super-majority of the remaining non-national judges would be required in order to achieve an

\footnotetext{
${ }^{75}$ Id. at 385

${ }^{76}$ In the sense understood by Franck; see Thomas Franck, The Power of Legitimacy among Nations (1990). At 19, Franck defines legitimacy as "the perception of those addressed by a rule or a rule-making institution that the rule or institution has come into being and operates in accordance with generally accepted principles of right process."

${ }^{77}$ Lauterpacht, supra note 68 at 385
} 
overall majority (that is, with all three national judges voting in favour of the impleaded state's position, 8 of 11 would be needed in order to produce a majority, namely $8-6$, with 7 only being enough to produce a tie vote of 7-7). Lauterpacht may be making more than an empirical observation, however. He would seem to be attributing enhanced normative force to a representational scheme that requires a very large non-national vote in order to prevail over a unified national vote for a contrary result; recall that in the first of the above quotations, his goal seems to be the avoidance of negative rulings "given by a small majority of foreign judges." 78 Viewed in this way, the scheme is designed to make sure that the permanent court of 11 judges must vote by at least 8-3 in order to decide a case against a state in the face of all of that state's national judges preferring to find in favour of the state. Lauterpacht may, inchoately, have been getting at an aspect of procedural fairness in the sense of Thomas Franck's "right process." 79 One can analogize to the traditional notion of the right to a fair hearing. The premise appears to be that a state (or, state-society) is likely to view a judgment as possessing enough legitimacy to be obeyed if the process of judgment is such that members of the state government (or members of the state-society as a whole) can feel content that their view of the matter has been heard and taken seriously in the intracourt deliberations, even if that view had not been convincing enough to bring more than a few non-national judges on board.

So, on Lauterpacht's conception, a court, in ruling without any national judges joining the majority, would still be ruling as a "purely foreign tribunal," but will have done so having been well apprised of all the factors speaking in favour of upholding the law or government (in)action. We get some sense of this when Lauterpacht comments (albeit as a separate thought and not one directly tied to the issue of the foreignness of the judgment):

Moreover, some such modification of the composition of the Court in individual cases would go a long way towards meeting the objection that a foreign tribunal, not conversant with the laws and traditions of the State, is called upon to pronounce on matters

\footnotetext{
${ }^{78}$ Id. (emphasis added).

${ }^{79}$ Franck, supra note 76 at 19.
} 
touching the very core of national life and of national sovereignty. ${ }^{80}$

In Lauterpacht's reasoning, "international" is synonymous with "foreign" in situations where there are no national judges involved in the international decision-making process. It is the inclusion of national judges that produces some kind of transformation of the "foreign". This transformation can perhaps be understood in some metaphorical fashion as the nationalizing of the foreign (whether this results from the participation of the national judges in the majority decision - thick nationalization - or merely from the participation of these judges in the deliberations of the court as a whole - thin nationalization). This is only one part of the explanation of how the Court is de-foreignized through Lauterpacht's proposed procedure of enhanced national representation, however. Another (the other?) part is the inter-nationalizing of the foreign. I employ the hyphenated formulation "inter-national" here in order to emphasize the element of intersubjective horizontality that is achieved (or, at least, aimed at) by the enhanced representation formula proposed by Lauterpacht. The judgment loses the 'international as extra-national' quality that would result in the equation of "international" with "foreign" and assumes (some degree of) an 'international as inter-national' quality. In this way, the international human rights treaty that is the subject of interpretation can be viewed as site of continually negotiated normativity in the space between self-judgment and other-judgment. The treaty is neither national nor international - that is, it is a shared inter-national space - and it is both national and international - that is, both the national and extra-national elements are still identifiable, even if they merge to some extent in what John Rawls has called an overlapping consensus. ${ }^{81}$ Indeed, Lauterpacht

${ }^{80}$ Lauterpacht, supra note 68 at 385 (emphasis added). This is of course the main public justification for the current requirement that a national judge sit on each case brought against a given state under the European Convention.

${ }^{81}$ For the initial invocation of the notion of an "overlapping consensus" capable of being affirmed by opposing philosophical doctrines, see John Rawls, The Idea of an Overlapping Consensus 7 Oxford J. Leg. Stud. 1 (1987). The notion is easily extendible to the process of reaching agreement in a multiple-member court whereby national and foreign judges, seeking to pen collectively a majority judgment, come to agree on shared language (usually at sufficiently intermediate levels of abstraction to secure consensus), even if they individually diverge on the deeper reasons that justify this formulation. The idea of an overlapping consensus can also shed some light on the situation in which 
ends his discussion of enhanced representation with a recognition of the hybridity of legal orders implied by his representational scheme: "There may also be some wider significance in an attempt, implied in the proposal here put forward, at a combination of - and the raising of the rigid barrier between - national and international jurisdiction." 82

\section{DIVERSITY OF KNOWLEDGE, COMMUNICATION AND TRANSNATIONAL INSTITUTIONAL AUTHORITY}

Were an international human rights court again to be on the agenda some 60 years after Lauterpacht's creative exercise in institutional design, would we be well advised to continue to perceive, with Lauterpacht, that the key is to find ways to build the national into the extra-national so that binding international judgment can be sufficiently justified as an acceptable incursion into sovereign juridical space? In this part, I give a qualified 'no' in answer to this question by arguing that there are more relevant axes of representation for enhancing the persuasive authority of an international human rights institution than radically incomplete schemes for conjuring some creative non-fiction that an irreducibly nonnational judgment is actually national in its crucial aspect. In the concluding part, Part 6, I return, however, to the still-lingering problem of the international as external in order to suggest that this problem should be approached in ways other than through - or, at least, in addition to - the representational composition of representation within international human rights bodies.

The main purpose of this part, then, is to elaborate the theoretical justifications for promoting "interactive diversity of knowledge." This notion was initially presented, in somewhat summary fashion, in another work called "Bodies of Knowledge" for which the context is set by recent recommendations that a consolidation of the six UN human rights treaty

foreign judges are sensitive to the use of reasoning in the majority judgment that attends to concerns voiced by the national judges who still dissent from the result.

${ }^{82}$ Lauterpacht, supra note 68 at ${ }^{385 .}$ 
bodies into one or two bodies should be on the UN reform agenda. ${ }^{83} \mathrm{My}$ argument was that a harnessing of diversity must be central to any consolidation reforms and that diversity-enhancing initiatives must be undertaken immediately with respect to the current six-committee order, in part because practical experimentation with the promotion of diversity will provide valuable lessons at the institutional design stages of any eventual consolidation project. But the central thrust of the argument is that such an approach is independently desirable quite apart from whether treaty-body consolidation is in the cards. Two premises are central. The first is that superior collective judgment is exercised when multiple perspectives are encouraged to interact with each other in coming to grips with any given normative issue or decision. The second premise is that, in order for diverse perspectives and actors to interact, there must first be a commitment to ensuring diversity within the composition of the membership of collective decision-making bodies. Diversity multiplies perspectives, while the need for decision-making necessitates that these perspectives engage each other. Diversity helps oust monological reasoning in favour of dialogical reasoning, making it less likely that reasoning will take place within the four corners of a single person's limited knowledge and more likely that it will take place in the context of the requirement to test one's assumptions and intuitions against those of others. The operative good of a "dialogical universalism" is knowledge and the perspectives that adhere to knowledge. In somewhat oversimplified terms, we can think of "social experience" and "disciplinary expertise" as the two main forms of knowledge relevant to the juridical construction of normative knowledge. ${ }^{84}$

${ }^{83}$ Craig Scott, Bodies of Knowledge: A Diversity Promotion Role for the UN High Commissioner for Human Rights, in The Future of UN Human Rights Monitoring 403 (Philip Alston \& James Crawford, eds., 2000).

${ }^{84}$ Scott, id. Section B: "Valuing Diversity of Knowledge", 406-11. It is important to acknowledge that expertise and experience are overlapping forms of knowledge. This point will not be developed in the present chapter beyond the note that informal experience can be said to generate a type of expertise, while formal expertise is often incomplete or underdeveloped if it lacks experience of the world or of the issues being studied. For development of a third form of knowledge mentioned in Bodies of Knowledge, that of normative focus, see Scott, supra note 31 at 8-9 
In the present part, there is be a shift in relative emphasis. As noted, Bodies of Knowledge focused mostly on how interactive diversity is more likely to produce results which are qualitatively superior to those produced by more monological processes of decision-making. As such, the emphasis there is mostly on the positive instrumental contribution of representational diversity to substantive performance, and, as such, to both the specific authority of each interpretive result and the overall authority of a given juridical institution. The discussion in the present section merges this substantive virtue with a more process-oriented account of general institutional authority. This account seeks to explain how interactive diversity places an institution in a better position to claim (democratic) legitimacy for the judgments it produces. ${ }^{85}$ Part of the argument is that attention must be paid not only to the dialogical authority of the institutional collective, but also to the dialogical ethos of each individual member of that collective.

\section{A. COMmunicative Legitimacy, Verticalization OF InSTITUTIONAL DECISION AND REPRESENTATIVE SURROGACY}

Support for the principle of the interactive diversity of knowledge can be found in what might seem to some an unlikely source within mainstream international legal scholarship, namely, the long-standing theoretical work pioneered by Myres McDougal and Harold Lasswell at Yale with their several collaborators. McDougal and Lasswell advocated thinking of law as a process of communication in which an instrumental orientation towards the pursuit of common interest(s) coincides with a requirement that decision-making institutions incorporate a range of perspectives. They developed a highly regimented and complex methodology which included principles designed to enhance the capacity of any given decision-maker to take into account the perspectives of all persons and communities affected by a contemplated decision, with the objective of thereby

\footnotetext{
${ }^{85}$ Here, it is important to note that "democratic" is used in a general normative sense to signal the ideal of the effective involvement of those affected by decisions in the governing arrangements that produce those decisions and is not an endorsement of any specific form of political democracy as a necessary precondition for a state-society's right to be part of the international human rights treaty order.
} 
achieving a kind of perspective of perspectives. ${ }^{86}$ Elements of a philosophy of strong diversity can be discerned in their theory - at least, in its implications while certainly not always in the specific articulations or real-world applications of it by its founders. According to this philosophy, communication across markers of difference is necessary in order to approximate the regulative ideal of the perspective of humankind as a whole. On this approach, legitimacy is directly tied to as wide as possible a - ideally a universal - sharing of power. The key premise is that the participation of affected persons and groups enhances both the political legitimacy and the substantive quality of the prescriptions that emerge from any given decision. ${ }^{87}$ With the reader's indulgence, a collage of extracts is cut and pasted below in order to convey how diversity fits within the line of reasoning advocated by the New Haven approach:

The overriding policy is that of universality: all who are affected by, or who can affect, authoritative decisions should, or should be made to, participate in the making of such decisions. . . . The wide sharing of power requires both pluralism and equality. All individuals and groups who are affected by decisions should be represented in such decisions, both functionally and territorially. . .

${ }^{86}$ See, in particular, Myres McDougal, Harold Lasswell \& Lung-Chu Chen, Human Rights and World Public Order 367-368, 372 (1980):

The deliberately policy-oriented, configurative approach we recommend for inquiry about human rights problems, as for all legal problems, begins with the unequivocal establishment of an observational standpoint in identification with the whole of humankind and with the explicit postulation of a comprehensive set of preferences, formulated at a necessarily high level of abstraction, about the shaping and sharing of all human dignity values. . . The prescriber or applier or other evaluator of policy options has an obligation to make himself as conscious as possible of the full range of communities, from global to local, of which he is a member and upon which his choices will have unavoidable impact.

${ }^{87}$ Alongside political legitimacy and substantive quality (qua functional performance) as elements of persuasive authority, there is also a strategic dimension which interacts with the other two, namely, effectiveness. On effective strategy as a reason for choosing dialogue as a method in human rights interpretation, in addition to questions of political, as well as cultural legitimacy, see Abdullahi Ahmed An-Na'im, Toward a Cross-Cultural Approach to Defining International Standards of Human Rights: The Meaning of Cruel, Inhuman or Degrading Treatment or Punishment in, Human Rights in Cross-Cultural Perspectives: A Quest for Consensus (Abdullahi Ahmed An-Na'im ed., 1992). 
The constituent perspectives appropriate to a public order of human dignity should be directed toward the clarification and protection of common interests (significantly affecting all) and the rejection of claims of special interests (destructive of common interests). . . . The identifications of established decision-makers, as of community members, should be encouraged to extend to the larger community of humankind and all its component communities. For the better clarification and integration of the common interest, an appropriate balance should be sought for decision-makers in terms of culture, class, group membership, and personality. . . . Established decision-makers, again like community members, should explicitly examine their expectations, or matter-of-fact assumptions, about the conditions under which demanded values can be secured. The most realistic orientation requires unceasing effort to improve structures and procedures for inquiry and communication. ${ }^{88}$

From this composite passage, we can see that the idea of diversity and universality going hand in hand is central to the New Haven idea of (international) law as a process of authoritative decision-making. The bridge between the two is provided by communication - by interactive diversity. It is only by starting from real-world differences in perspective

\footnotetext{
${ }^{88}$ McDougal, Lasswell \& Chen, supra note 86, at 400-02 (emphasis added). While this is not the occasion to engage in subtextual analysis of the authors' use of the concept of "special interests", I do wish to make clear that McDougal, Lasswell \& Chen and I do not always share the same conceptions in relation to the concepts they employ. For example, the following passage possibly shares some space with prevailing conservative conceptions which deny the relevance of diversity of social experience to law: "Participation in decision should be upon the basis of equality in interest, without discrimination irrelevant to merit and contribution and without minorities being authorized to make policies for the whole", id. at 401. This passage is to be read in light of the authors' earlier observation of the tendency for humans to "refer to ourselves and others with labels (such as race, color) having no rational relation to basic humanity or to potential contributions to the common interest", id. at 46. The basic thrust of their claim about the irrelevance of 'race' is undeniable to the extent that it is understood as a denial of particularistic essentialism and of any socially constructed claims of superiority based on markers such as race or colour, but the added claim that such labels are irrelevant as "potential contributions to the common interest" can all too easily be read as denying the relevance of social groups' concrete historical and social experience of racialization to our general understanding the common interest.
} 
and in community membership, partly by paying attention to the composition of institutional decision-makers and partly by engaging in critical self-examination of one's assumptions, that communication as dialogical engagement can take place.

In many respects, the McDougal and Lasswell approach to (international) law has paralleled and even presaged contemporary theoretical writings that centre on what is variously called communicative ethics, discourse ethics, and dialogical ethics. ${ }^{89}$ According to such an ethics, legal norms are legitimate to the extent that they have been or can be treated as if they are generated intersubjectively through pluralistic communicative engagement. Jürgen Habermas, for example, arrives at an ideal "discourse principle" not dissimilar in formula to the "overriding policy of universality" posited by McDougal, Lasswell and Chen in the abovequoted passage. According to this principle, "the only regulations and ways of acting that can claim legitimacy are those to which all who are possibly affected could assent as participants in rational discourses". 90 This principle then serves as a premise for the claim that the ideal institutional form of such participatory legitimacy is for "citizens [to] test which rights they should mutually accord one another". 91

Such citizen-to-citizen engagement is of course a regulative ideal, not a sociological possibility, in the decision-making contexts of most modern polities. ${ }^{92}$ By signalling from the outset the counterfactual nature of the ideal ("could assent"), the Habermasian discourse principle builds in

${ }^{89}$ For an especially-useful anthology, see The Communicative Ethics Controversy (Seyla Benhabib \& Fred Dallmyr eds., 1993).

90 Jürgen Habermas, Between Facts and Norms: Contributions to a Discourse Theory of Law and Democracy 458 (1996). The initial articulations of Habermas on the discourse principle started at around the same time as McDougal and Lasswell were beginning their collaborations.

${ }^{91}$ Id..

${ }^{92}$ Of course, even if it were viable, such engagement could still only be a co-ideal when other considerations are brought into play, such as the need for sufficiently efficient, stable and timely regulation of common life and the need for human beings to balance their status and responsibilities as political beings with the other spheres of human endeavour and fulfilment that pull them in many directions at once. 
recognition of the basic problem that the ideal of participatory democracy is not an institutionally viable form of law-making (including lawinterpreting) outside very small communities, and, even then, it is probably only applicable in its purest sense to certain kinds of normative problems. As such, the citizen-citizen (or, as I prefer, person-person) public discourse that Habermas uses as the benchmark for ideal legitimacy must be translated into an analysis of how well different forms of institutionalization of decision-making embody this ideal. The result is that we move of necessity from a focus on direct participation to a focus on indirect participation through representation.

The ideal of horizontal (interpersonal and intrasocietal) discourse thus does not disappear in the move to vertical institutionalization. Rather, it insinuates itself as a structural problem for the design of the institution both in terms of composition and procedures. How can an institution organize itself and then present itself as a legitimate substitute for pure participation? The answer must take at least two forms. Firstly, the discourse principle must be transformed into a more concrete principle according to which the institution must seek to function to the extent that is practically feasible as a surrogate or microcosm of the relevant community of persons. It must aim for, while of course never achieving, the replication of the interpersonal participatory dialogues that are the posited democratic ideal. One consequence of such a surrogacy principle is that the composition of the body must be such that dialogue within the institution simulates, as it were, these (ideal) dialogues within society at large; this is the concern about representivity and diversity. Secondly, the institution must not be thought of as a self-contained microcosm in which the members only have to engage in a dialogue internal to the institution. However much persuasive moral authority can be generated by implicit or explicit appeals both to the representativeness of the institution and to the dialogical process within the institution that precedes a given decision, the ideal of incorporating the perspectives of all affected persons and groups as a surrogate for actual participation can only be approached, not reached, within the confines of any given institution. This being so, we are always constrained to work with degrees of approximation of ideal interactive diversity in society. It therefore in some sense follows that, in addition to representative dialogue internal to the institution, the institution as a collectivity must also be imagined as a participant in ongoing dialogues with the society and polity at large. This externally oriented participation 
may take many concrete forms. It can involve dialogues with other institutions which have normative mandates covering the same or related areas. ${ }^{93}$ It can also involve stimulation of wider social debate (for instance, via the general news media or in professional publications) to which the institution can then listen and respond.

\section{B. BREAKING BAD HABITUS}

As a condition for the legitimacy of judgment not only do others need to be represented in deliberations, but also those representatives cannot share so much of what a leading European sociologist has termed habitus that they are scarcely challenged to imagine how normative issues might look if approached from outside the confines of their existing knowledge framework. ${ }^{94}$ To fully appreciate this, we need actively to cultivate a healthy sense of how we take much for granted that, once queried by those with different perspectives, seems to be less firmly grounded than our earlier complacence would justify.

My own experience working in the field of social and economic rights for a number of years and attempting to relate that doctrinal field to the realities of a life lived in poverty has convinced me of how very difficult it is fully to understand even with the best faith and considerable effort that

93 For example: courts interacting with legislatures or with administrative agencies; international human rights institutions interacting with states, with specialized agencies, with regional human rights bodies, or with the non-governmental sector; human rights committees interacting inter se; and so on.

94 To modify a colloquialism, such a deliberative practice would, in its most extreme form, amount to mutual preaching by the converted to the converted. Pierre Bourdieu's idea of habitus can be paraphrased as a reference to the constellation of dispositions, baseline assumptions and world views that are embodied in a group of persons, such habitus being structured, inter alia, by a person's present location in social hierarchies, as well as by formative influences such as social group experience and educational upbringing (notably professional elite formation). While I believe that we can speak meaningfully of each person having her or his own unique habitus, the primary sense of habitus is of a shared phenomenon, "[ $\mathrm{t}$ ] he conditionings associated with a particular class of conditions of existence" that operate at some subconscious level on the behaviour of those imbued with such habitus; they are "structured structures predisposed to function as structuring structures”. See Pierre Bourdieu, The Logic of Practice 53 (1990). 
which is not one's own experience or area of expertise. I am constantly amazed at the layers of meaning I fail to grasp that get drawn to my attention when I hear those living in poverty recount the nature of the harms and indignities they experience and, more importantly, perceptively analyse the complex interaction of social forces and official behaviour that contributes to these experiences and that creates barriers to extrication. That being said, it is also significant that I find myself equally amazed by how well some people who work on a regular basis on behalf of and with poor people can understand the experience of poverty even when they are themselves economically well off. These foregoing observations are deliberately intended to be unsystematic. The only point I wish to convey is that, even if we are comparatively privileged (on one or more dimensions), most of us should be able to appreciate the difference diversity can make by recalling our own periodic self-awareness about the limits of our own perspectives and by appreciating the value of the contribution that diverse perspectives have made to our own understanding in certain contexts. By working with such meta-experience (experience of our own insufficient experience), we can encourage ourselves to approach normative issues by seeking to understand the kinds of perspectives that will help broaden horizons and, as such, help prevent a given institutional decision-making context from succumbing to conceptual gridlock. ${ }^{95}$

95 I could multiply my own anecdotes. Another influential 'meta-experience' for me was my role as coordinating instructor for six years of a short course called "Race and Cultural Difference". It was a mandatory, one-week intensive course for all first-year law students that was one component of an overall course called "Perspectives on Law". A central objective of the course was to introduce students to issues surrounding racism and ethnocentrism in legal systems and in legal philosophy. As a Caucasian male of AngloSaxon heritage, my own direct experience of being at the receiving end of these phenomena in Canada, either in society at large or at the hands of the legal system, is essentially non-existent. Despite working on this course for all these years and despite my pedagogical policy of bringing in outside community speakers and other university teachers more able to relate experience to both theory and legal practice, I remained painfully aware of the limits of my own understanding. The lesson I have drawn: one learns, but one does not fully learn; one can intensify one's learning, marshalling all one's time and energy in so doing, and one would still only learn so much.

In Canada, for example, judges are increasingly acknowledging the importance of the inclusion of diverse perspectives, albeit sometimes only in terms which speak to what they will bring to a court that others cannot. It is a short step from realizing the value of one's own distinct perspective to welcoming the inclusion of others' perspectives with which one can interact. For example, Justice Gérard La Forest resigned 
from the Supreme Court of Canada in 1997. He is a white male francophone who is a bilingual member of the minority French-speaking Acadian community in the province of New Brunswick, which is one of the four provinces on Canada's Atlantic coast. He is also a former law professor who was considered the leading (indeed, the only) international law specialist on the Court. In Canada, there is a non-binding convention that the Prime Minister will appoint judges to the Supreme Court based on a certain geographical distribution (three judges from Québec and three from Ontario, one judge from British Columbia, one judge from the three Western Prairie provinces combined, and one judge from the four Eastern Atlantic Provinces combined). Prior to Prime Minister Chrétien's appointment of La Forest's replacement, much discussion centred on the various demographic criteria the Prime Minister should consider in choosing this one person. It was generally assumed that the replacement would also come from the Atlantic Provinces, and it was also assumed that a judge from one of the three provinces other than New Brunswick would get the nod. As there are only two women on the Court (down from a high of three at one point), many argued that gender was a highly salient criterion. Others focused on professional skills.

In the result, the Prime Minister appointed another white male francophone from New Brunswick, Mr. Justice Michel Bastarache. Intraregional diversity and gender diversity appear to have given way to an emphasis on diversity of juridical expertise and the continuing worth of including a member of a minority French-language community. In terms of the Court's expertise gaps, one should recall that La Forest was the Court's only international lawyer and that Bastarache has a graduate degree in international law. As well, Bastarache has served as a legal academic, indeed (like La Forest) a dean of law at one of Canada's law schools. This form of legal expertise was singled out by La Forest's daughter, herself Dean of Law at the University of New Brunswick, when interviewed on her father's replacement:

[I]n the end, the issue that really counts is one of quality, not geography or gender. These people [Supreme Court judges] are making extremely important decisions. The court needed an academic to replace my father. As an academic, you develop different skills; a reflective balancing of the issues [is] involved.

Quoted by Kirk Makin, Top Court Choice Humbles Prophets: N. B. Francophone Replacing Same, The Globe and Mail, October 2, 1997 at A1. To be noted is that Dean La Forest's comments about quality were related to the juridical needs - the expertise needs - of the court and made no claim that Judge Bastarache was purely and simply the best jurist (in some overall sense) in the pool.

Interestingly, in a few short sentences, Justice Bastarache himself encapsulated what he can bring to the Court in terms not just of expertise but of diversity of experience and expertise combined:

Asked to name the chief strength he brings to the court, Judge Bastarache cited his varied legal background. 'It brings in a kind of experience of life that is different from others who are practitioners all their lives,' he said. 
Part of the rationale for an institutional strategy of opening up normative vistas by embracing an interactive diversity of knowledge lies in selfconscious awareness of the (human?) tendency to link 'truth' and 'selfevidence' in untenable ways. It is probably safe to say that most of us who actively take part in international human rights discourse are striving to articulate something morally fundamental in the course of our involvement; indeed, many of us would feel lost without such an orientation to the enterprise in which we are engaged., That does not mean that we must necessarily believe that concepts in texts like "freedom of expression" or even "torture" correspond to some 'objective' moral reality waiting to be discovered in the moral firmament, however. Even if some or many - of us do firmly believe that some correspondence (or, perhaps more subtly, idea of correspondence) between language and the revelation of something called moral reality is a meaningful or even necessary way of thinking, such belief is still compatible with an awareness that what we may speak of or argue about in terms of objectivity or universal validity or truth is never knowable other than in terms of what we (whoever 'we' are) understand to be objective or universal or true at a given point in time. ${ }^{96}$ Our access to meaning is mediated by language, and language is a phenomenon constructed on the shifting ground of intersubjective understanding. Thus, whatever quest(s) for truth may be immanent in our various involvements in the international human rights project, meaning

'I am also a francophone, but not from Québec. That also brings a different perspective. I think it is important for the court to have the point of view of the sort of person who is impacted by their interpretation of these [minority] rights. I don't think somebody of the majority-language group can understand how in daily life they are impacted by their decisions.'

Makin, id. at A4 (emphasis added).

96 We can never 'know' in any final way whether an understanding we have reached intersubjectively is valid in any sense beyond the intersubjective. So, whatever we do to reduce subjectivity by enhancing intersubjectivity, we must still adhere to a certain ethic of communitarianism that compels us to defer to the judgments of authoritative institutions even when we perceive given decisions as wrong. It is fidelity to the goodfaith process of reaching for the moral insight embedded in the notion of human rights, not fidelity to each and every product of that process, that is the claim legitimate authority makes on us. That being said, there are limits to this fidelity. The more an official decision-making process is perceived as inadequately intersubjective, the more likely defections from respect for specific decisions will become. 
remains quintessentially human - fallible in its relationship to that (ultimate) truth we seek. Thus, each of us has good reason to be humble about our knowledge. Indeed, we have good reason to be positively suspicious of our own understandings to the extent that they have been produced unreflectively or outside conditions of dialogical diversity. ${ }^{97}$

Therefore, the quality of the intersubjectivity(ies) in which understandings are located must be a point of critical focus in assessing institutional judgments. Specifically, each of us should want to make sure each of our judgments are thoroughly tested by as wide and diverse a range of people as is practically feasible. In terms of the external addressees of an institutional decision, the outsiders faced with the judgment have an important reason to be confident in the rectitude of the decision if they can see that a group of people with diverse knowledge backgrounds have come to a consensus or achieved a large majority. This does not necessarily mean either agreeing with the result or being persuaded by the substantive reasoning of a given judgment. It means only that, within the representational imperatives of the institution, there is reason to accord the institution some general authority. By representational imperatives, I mean the indices that are (that is, that appear to us to be) most salient in order to achieve the fullest grasp of the issues at stake according to the normative focus of that institution. So, for example, one might feel that it is unjustified that an institution be composed entirely of persons trained in law, perhaps because one feels that lawyers, as a generally privileged group, are disabled from fully appreciating the social meanings generated by less powerful social groups. If that same institution were nonetheless diverse in one or more other relevant dimensions, such as gender or cultural background, however, a general authority for the decisional product of that institution would be generated in some kind of direct relation to the effective incorporation of that element of diversity in the institution's deliberations. The assumption that a more (effectively) inclusive process enhances the quality of deliberation and thus makes some difference to substantive outcomes allows us to be more respectful

97 Thus, ideas such as "epistemological humility" and "hermeneutics of suspicion" have had considerable currency in writing on interpretation over recent decades. These ideas express the warning that we must be on our guard against the effects privileged social location might have on our powers of social criticism and on our reception of the arguments of others. 
of decisions which affect us, but with which we disagree, as compared to our possible reaction to decisions produced by a more sectarian group of decision-makers. ${ }^{98}$ If that institution (composed, for example, of 18 individuals as are four of the six UN human human rights treaty bodies) came to include more people with professional backgrounds or personal career paths other than law, then the general authority that one should be willing to accord the institution would increase even if we can never be certain that any given outcome would have been different if the institution had been less diverse. Authority here is generated not simply by the possibility, or even probability, that the inclusion of diverse perspectives has led to an outcome which would have been different if that diversity had not been in place. Rather, it is generated by the sense of assurance that a common or significant majority position could not have easily evolved through indifference to difference.

What angles of vision will be most salient will depend on the field in question. $^{99}$ For example, the value of a certain form of geographic diversity in the international human rights context is illustrated by an observation made by Rosalyn Higgins in recollecting her years on the Human Rights Committee. ${ }^{100}$ She gives the example of how some Committee members from countries in the South took strong issue with European members on the question of whether the fair trial provisions in Article 14 of the ICCPR should extend to include administrative proceedings. The European Court of Human Rights had begun to expand

${ }^{98}$ See Jeremy Waldron, A Right-Based Critique of Constitutional Rights 13 Oxford J. Legal Stud. 18 (1993): "[D]ebate has a point: to use collective interaction as a way of reaching towards complicated truth. Simple truths, self-evident truths . . . form in single minds".

\footnotetext{
99 “Angles of vision" is Jennifer Nedelsky's phrase: “The more angles of vision we are capable of taking into account in our judgment, the more we can free ourselves of the limitations of our private conditions. When we are locked into one perspective, whether through fear, anger, ignorance, or even through our notions of virtues such as duty, courage, or responsibility, we are not judging freely." Jennifer Nedelsky, Judgment, Diversity and Relational Autonomy, J. A. Corry Lecture, Queen's University, October 1995 (unpublished manuscript) [Note to SSRN readers: An updated citation will likely be substituted here.]

${ }^{100}$ Rosalyn Higgins, Opinion, Ten Years on the UN Human Rights Committee: Some Thoughts upon Parting, 6 Eur. Hum.Rts L. Rev. 570 (1996).
} 
the scope of the equivalent article (Article 6) in the European Convention, resulting in a convoluted and unsatisfactory jurisprudence, and decidedly negative reactions from a number of European states. This European experience was no doubt a consideration motivating some of the European members of the Committee to "urge[] that it would be utterly unreasonable to impose such a burden upon developing countries". ${ }^{101}$ Yet, as Higgins goes on to note, many Committee members from developing countries took exception in the deliberations to this position of the European members, "urging us to realize that it was in the area of administrative law that so much abuse took place in their countries". ${ }^{102}$

Perspective does matter, and an important perspective is not always the perspective that one would expect to hear if one were called upon to speak for others instead of allowing others to speak for themselves. Higgins' revealing anecdote goes a long way towards explaining why we should care about diversity generally, not simply some measure of geographical diversity. Had the Human Rights Committee been composed solely of members from European countries, there would have been a decreased likelihood that viewpoints grounded in the lived reality of developing countries would be taken into account. The same relationship must exist between the degree of inclusion of other indices of experience (and the associated knowledge) and the quality of collective deliberation.

All that being said, it remains important here not to essentialize what it means to be from a developing country - or to have a particular gender or sexual orientation, or to have been raised in poverty, or to be dark-skinned in a majority light-skinned society. ${ }^{103}$ The claim is only that there is a decreased likelihood of relevant perspectives being taken into account if

\footnotetext{
${ }^{101}$ Id. at 575.

102 Higgins is not explicit about the result of the perspective of the members from countries of the South having been taken into account, but the case she was referring to as Landry resulted in the question being left open of the Application of ICCPR Article 14 to administrative proceedings involving social rights. See Y. L. v. Canada, Communication No. 112/1981, HRLJ 281(1986); see also the discussion of this case in Craig Scott, The Interdependence and Permeability of Human Rights Norms: Towards a Partial Fusion of the International Covenants on Human Rights 27 Osgoode Hall L. J. 769,864-68 (1989).

${ }^{103}$ See subsection 5.d., infra, for further discussion of the essentialization objection.
} 
we exclude persons with certain backgrounds. It is of course the case that each of us achieves access to knowledge outside our dominant social experience or professional formation in many ways other than engaging persons 'representing' that area of knowledge in face-to-face dialogue. Quite apart from the myriad forms of exposure of a given person to lives outside her or his own immediate experience, one of the functions of legal procedures is to provide means for other knowledge to be introduced into evidence, legal argument and judicial deliberation. ${ }^{104}$ Yet, even in a modern world of increasingly cosmopolitan education and more widespread global communications, we would be mistaken to be complacent with knowledge that is not meaningfully direct either in terms of experience or sustained study. Drawing again on the Higgins anecdote, one could easily assume that a number of the Committee members from European countries would claim with some justification to possess knowledge about conditions in certain developing countries. But the different perspective of at least some of the members from such countries suggests just how dangerous it is to rely on ephemeral or indirect knowledge and how easy it is to allow extrapolation from one's own experience to dominate one's thinking.

\section{The Individual Member In A Diverse Institution: RHETORICAL RESPONSIBILITY}

I wish now to advance several claims about the institutionalization of the principle of ideal participatory democracy. As already discussed, one claim is that a special kind of intra-institutional dialogue is required, and another is that the dialogue must be framed by a diversity of perspectives and thus be as 'representative' as feasible, in the sense of being, in

\footnotetext{
${ }^{104}$ A number of the practices of the committees serve this function, such as: the acceptance and use of information provided by NGOs at various stages of the committees' work, including in the form of alternative reports; the solicitation of information from specialized agencies of the UN; allowing NGO representatives to make oral presentations to a committee at the start of the committee's session (a practice initiated by the Committee on Economic, Social and Cultural Rights); NGO input into committee working groups which are preparing questions to be addressed to governments, and involvement of experts from outside the committees in discussions on general normative themes or on draft general comments.
} 
significant measure, a surrogate discourse for ideal society-wide dialogues. Another claim still, which I seek to develop somewhat in the present section, is that the persuasion of the self is an existential orientation that, if understood and approached in a certain way, is compatible with, and even facilitative of, dialogue with others. Diversity within the institution enriches the interior dialogue that any given person can hope to engage in. When diversity-based dialogue occurs among the members of the institution in parallel to a given person's internal dialogues, that person's dialogical imagination is stimulated in ways that are not possible if reflection occurs in a context where those interacting with the person are from very similar social backgrounds and training. The imagination requires contact with real others, and this is at least as much the case when the focus is on the persuasion of self as it is when the focus is on the persuasion of others. Seyla Benhabib has put it well:

Enlarged thought, which morally obligates us to think from the perspective of everyone else, politically requires the creation of institutions and practices whereby the voices and the perspectives of others, often unknown to us, can become expressed in their own right. A major mistake of Kantian moral theory is to assume that the principles of enlarged thought can be realized via the isolated thought experiments of a thinker. These solitary thought experiments often substitute the standpoint of the one privileged part for that of the whole. . . . The cultivation of one's moral imagination flourishes in such a culture in which the self-centred perspective of the individual is constantly challenged by the multiplicity and diversity of perspectives that constitute public life. ${ }^{105}$

In her reference to "principles of enlarged thought", Benhabib indicates that mere diversity of perspective and of membership is insufficient. Also required are certain ethical dispositions and associated modes of reflection.

105 Seyla Benhabib, Situating the Self: Gender, Community and Postmodernism in Contemporary Ethics 140-41(1992). 
In this regard, one further claim I would like to advance - which I will not fully justify here - is that a member of a representative institution must fully assume a rhetorical responsibility in relation to the substantive decisions reached. In the sense of the now-standard Habermasian formulation of the discourse principle introduced earlier, institutional legitimacy requires as full as possible an incorporation of the starting ideal that all those affected by a decision could assent if (counterfactually) they had participated in reaching the decision. This entails that the institution must, in some fashion, seek to persuade all those to whom its decisions are addressed that those decisions are justified (whether correct in a strong sense or at least reasonable in a context in which a standard of reasonableness is all that can or should be expected of a given institutional decision-maker). This duty to persuade is what I refer to as a rhetorical responsibility.

It is obvious that this is a fearsome responsibility. The multiple audiences of many institutions can only be imagined and never directly, let alone simultaneously, addressed except in the most general way. This is especially the case for the normative judgments of bodies, such as the UN human rights committees, that are meant to have a global scope. If each committee member must (ideally) ask whether she or he has signed onto or individually penned reasons that could be seen as valid by all those affected by the decision, each normative act by any one of the human rights committees would have to take into account every person in the world in every context and every intermediate social group or association affected in one way or another by its interpretative acts. Involving (as it must) some kind of positing of either the generic reasonable person, or a universal audience towards which persuasive efforts must be directed, this prescription is so purely counterfactual as to be an unhelpfully fictional exercise. What all of this seems to suggest is that the measure of the authority of the institution's external engagement with society at large cannot require some unattainable duty to persuade the world, but instead requires the adoption of more pragmatic or operational orientations with respect to how the institution and its members can take the duty to persuade seriously without being debilitated by it. In my view, it is both desirable and useful to forge an appreciation of the need for a certain orientation to argument as well as for a set of dispositions and a storehouse of methods that relieve the judge or committee member of the superhuman burden of having to persuade an elusive universal audience while still 
imposing upon the judge an obligation to strive to persuade herself that her argument should persuade those who are the most affected by a decision. ${ }^{106}$ My use of the modal term "should" acknowledges that there is a gap between the Habermasian formulation in communicative ethics (that a norm or decision must be such that it can be followed by all the affected or relevant others in the sense of being a decision that they could assent to) and the real world of legal decision-making: a judge lives with the knowledge that the ideal of persuasion through legal judgment always, in practice, must come to terms with a residual coercive aspect vis-à-vis those who cannot or will not accept some of the key values and premises in the judgment.

In relation to the Herculean aspirations of the New Haven project, I have argued in the past that we must consider a significant degree of impressionistic choice to be an endemic feature of interpretation in valueladen areas that require normative outcomes to have universal validity. ${ }^{107}$ To this observation, I would now add that we cannot and should not avoid acknowledging the huge element of decisional existentialism involved in acting as a human rights jurist at the international level. In varying degrees, any given normative act (a "judgment" of the European Court of Human Rights, or a "view" of the Human Rights Committee, or a "concluding observation" of the Committee on Economic, Social and Cultural Rights) is inevitably a projection of the identity of the persons participating in that normative act onto the world, a projection of their

\footnotetext{
${ }^{106}$ With two further assumptions being made: (a) those other persons are assumed to have a general good-faith commitment to the idea of human rights (whatever their interpretations of that idea might be) and (b) those other persons are assumed to have put themselves in the institutional decision-maker's shoes in terms of forming a view of the appropriateness of alternative interpretive conduct within that institutional role. These two assumptions quite obviously need further development than can be provided at present.

${ }^{107}$ Scott, supra note 102 at 828-29: "Th[e] observational and interpretative standpoint [recommended by McDougal, Lasswell and Chen, supra note 86] would try to approximate some kind of objective view from nowhere by means of a view from everywhere. Laudable as this may seem, one may be forgiven for wondering whether it is humanly possible, or merely an unrealistic Herculean approach to interpretation. I do not believe that we can avoid taking incomplete and somewhat impressionistic stabs at viewing human rights questions from the perspective of those upon whom the impact of choices is most immediately and intensely felt."
} 
ideas of law, justice, human rights and so on. If we situate persuasion in the context of the ever-present potential for an imperial projection of self, persuasion cannot simply be understood as something one does vis-à-vis others. Persuasion must also include a self-directed process in which the judge or committee member justifies to herself the choices she has made and the ultimate choice to send her conclusions forth into the world in a way that is intended to change that world. ${ }^{108}$

I am suggesting that a self-consciously existential turn towards judging oneself as judge usefully aligns the question of whether one can face the judgment of others with the question of whether those others should be persuaded. By directing attention to such an existential dimension of judgment, I am not thereby suggesting that persuasion is now to be conceived as solely a one-way phenomenon, but rather that it is also useful to perceive it as implicating self as opposed to implicating solely an imagined reasonable person or universal audience. Judging as persuasionof-self helps actualize other-oriented dialogue to the extent that it introduces a strong self-consciousness about our own situatedness. It invites us to know more about the person we already know best, but encourages us to look to others (and others' knowledge and perspectives) precisely in order to discover the limitations of our own situatedness and to begin to see what we did not see before.

A further assumption being made in advocating attention to the existential dimension of judging is that none of us are unitary beings. We are all dialogically constituted in that we have multiple experiences that influence us, multiple communities to which we feel some attachment, and multiple philosophies and ideologies that debate each other for our allegiance (variously contradicting each other and complementing each other). In a stronger sense, we may say that others inhabit us in that our identity is partly constituted and reconstituted by those others who have been and are significant in our lives. ${ }^{109}$ The extent of dialogicality varies, of course,

\footnotetext{
${ }^{108}$ And which may change that world in unintended and even uncontemplated ways.

109 See Charles Taylor, The Politics of Recognition, in Multiculturalism and the Politics of Recognition: An Essay 25, esp. 32-34 (1992); Edward E. Sampson, Celebrating the Other: A Dialogic Account of Human Nature (1993); James W. Wertsch, Voices of the Mind: A Sociocultural Approach to Mediated Action (1991).
} 
depending on a person's life history and depending on the extent pluralism infused the contexts that have helped mould the character.

This argument neither assumes rampant dialogicality as an empirical matter, nor perceives dialogicality as an unqualified good unto itself. I am claiming only that a modicum of dialogicality is a basic feature of existence - indeed, a basic human capacity - and that one measure of the ethical potential of dialogicality is the extent to which it provides a psychic tool chest that assists us in becoming aware of those strains of our identity that too often can align themselves with dominant forces or groups in society. ${ }^{110}$ In other words, awareness of our own dialogicality is like a switch that shines a spotlight on our monological tendencies, which in turn makes it more likely that we can engage in the most primordial requirement of dialogue that combines success and legitimacy: the explicit examination of our own expectations and starting assumptions. Approaching judging as a persuasion of self thus asks the judge or committee member to render herself dialogical - to become as many as possible of the salient others to whom one must listen in order to persuade.

\section{REPRESENTIVITY AND INDIVIDUALITY}

Some might wish to object that the entire project of composing institutions so as to optimize the interactive diversity of knowledge necessarily knocks up against a problematic underlying assumption that a given individual is a general representative of her or his social or professional group(s). I have earlier addressed, albeit briefly, this objection and refer the reader to that discussion. ${ }^{111}$ With these objections in mind, however, I would now like to add to my earlier response to those having concerns about the supposed essentializing tendencies in my arguments. Specifically, the justintroduced notion of rhetorical responsibility cannot rely on a very broadbrush method of seeking an interactive diversity of knowledge through a presumption of the existence of differences in relevant knowledge based

\footnotetext{
${ }^{110}$ Of course, internalized alignment with dominant values may come about even if a person does not belong (or is not recognized by herself or by others as belonging) to a dominant group.

${ }^{111}$ Scott, supra note 83 at 409-410.
} 
solely on the existence of differences in social experience and disciplinary expertise.

In striving to secure institutional representation for a relevant diversity of habitus, we cannot adopt a position that does not also simultaneously acknowledge the irreducible individuality of mindsets and viewpoints of members of decision-making institutions. However much each of us operates with unquestioned, socially-(in)formed or discipline-(in)formed assumptions, we also have a (generally underused) capacity to engage in the constant formation and reformation of personal philosophies by engaging in varying degrees of critical reflection. Such capacity allows any given person not only to stray from but also to challenge the social influences to which that person is exposed. ${ }^{112}$ Even granting that life and career histories exert considerable influence on embedded premises as well as on conscious beliefs, personal histories can vary immensely even within what otherwise might seem a quite

${ }^{112}$ An instructive example of judicial acknowledgement of how one's personal identity affects one's judging is found in the statement by Justice Gérard La Forest of the Supreme Court of Canada as he was announcing his retirement from the Court. While often labelled a conservative by many observers, he was quite activist the area of rights jurisprudence with respect to matters of privacy. He openly acknowledged how his votes in privacy-related cases are at some level an existential projection of his own identity:

I suppose I'm a very private person. I think there is a feeling in me that the individual is under grave danger with the coming of the new technologies where everything about you can be known, to your detriment, not to your help.

He also frankly addressed his own character in terms of the influence of his small "i" ideology:

[I]f I had a perception, it would be a cautious liberal. I like to see things progress, but at the same time, one must be aware of the ground one is stepping on. . . I'm conservative in the sense that I realize that the values around us are extremely important, but I'm also cognizant that one must face changes as they come along.

Sean Fine, Top Court to Lose La Forest: Retirement of New Brunswick Francophone Puts Chrétien on the Spot, The Globe and Mail, August 27, 1997, A1 at A8.

This passage is instructive not only because it shows a judge who is aware of ideological perspective, but also because it conveys some sense that we are all, to varying degrees, constituted by different ideological strains and are in that sense (among other senses) dialogical beings. 
homogenous social or professional group. As I argued in Bodies of Knowledge, however, one does not need to embrace essentialism as the basis for asserting the relevance of group-based experience. ${ }^{113}$ 'Groupness' of perspective is no less real for being contingent and for being non-comprehensive. Based on our knowledge of history and of current structures and power, we can make judgments about which differences are both especially pervasive in habitus formation and more salient than others from the perspective of the quality and legitimacy of institutional judgment in a given normative context. Assuming my arguments in Bodies of Knowledge on this score are persuasive, then it remains crucial that we seek to make sure that some perspectives are included through structured composition of decision-making bodies. Specifically, in light of the domination-challenging role of human rights discourse, there is reason to listen long and hard to experience and expertise that relates to the lives of the presumptively disadvantaged if we are to hope to fully embrace the imperative of taking rhetorical responsibility for our judgments. ${ }^{114}$

In Bodies of Knowledge, I draw on the jury as an analogy for thinking about intra-institutional diversity. Returning to that analogy may help make the preceding points more concrete. In the jury context, affirmative

${ }^{113}$ Scott, supra note 85 at 409 .

${ }^{114}$ As I have put the matter before:

If we know that the world (including the world of the UN) is organized in such a way that certain perspectives are privileged, the call for inclusion appeals to the ideal of universality that is being compromised as the basis for an imperative need to introduce a kind of counter-privileging energy into the system. In this sense, we can justify a notion of the priority of perspectives as structured by an over-all substantive commitment to the elimination of suffering, of intolerance, of cruelty.

Craig Scott, Commentary on Part IV: Human Rights, in United Nations Reform: Looking Ahead after Fifty Years 168, 168-69 (Eric Fawcett \& Hannah Newcombe, eds., 1995). This does not mean absolute deference to what sufferers argue either to be the empirical truth, or the just normative prescription, but it does mean operating with a certain presumptive deference. See Scott, supra note 102 at 786-789: "From the vantage point of the underside of history, the intimate relationship between [sic] all human rights has a potential grounding in social experience and a resultant meaning that may be far ahead of understandings generated in less oppressive conditions." 
attention to diversity does not have to mean that we are seeking to make a jury even an approximate demographic microcosm of society, far less that we are seeking to translate societal numbers precisely and formalistically into proportionate numbers of "representatives" on the jury. For example, if, in a given trial, we have reason to believe that either homophobia or simple ignorance about sexual diversity might affect how a jury understands the evidence or how it looks on the victim, the accused, or witnesses, then sexuality is a salient demographic marker for purposes of taking seriously the normative function of a jury. However, we should be wary of assuming we have attended to the relevant concerns if we make sure one of the 12 jurors is an openly gay man on the ground that it is generally considered that only five to ten per cent of the general population are gay. Such a formalistic approach is akin to a theory of democratic legitimacy based solely on representation by population. While perhaps an advance on a concept of pure majoritarian democracy, it nonetheless fails to take into account the operations of power in society. We should instead be concerned to make sure that subordinated perspectives can hold their own in deliberations and thereby truly contribute to a dialogical deliberation. ${ }^{115}$

At the same time, one cannot go so far in the direction of the inclusion of 'representatives' of groups which are of central concern to human rights protections that we begin to think of inclusion as some kind of panacea. We cannot lose sight of the more broadly based normative function of the international human rights treaty bodies, that is, to exercise judgment in a way that has some chance of persuading all those affected by the judgments, including those who currently enjoy power and privilege in state-societies and who must be relied upon to change laws and practices in order to give effect to a view or concluding observation of a UN human rights committee. This is not to say that we should not assume (and even base legal presumptions around the fact) that the insights of the disadvantaged into the requirements of justice are generally more acute and accurate than those of the advantaged. Nevertheless, judgments which aspire to be broadly persuasive cannot hope to be so if they are too easily viewed (and then discounted or even dismissed) as the direct emanations

${ }^{115}$ Some studies suggest that perspectives need a critical mass to hold their own and to be taken seriously by the majority in deliberative processes. See for example Sheri L. Johnson, Black Innocence and the White Jury 83 Mich. L. Rev.1611 (1984). 
of the will of the poor, of women, of sexual minorities, of minority ethnic and racial groups, or, indeed, of nutritionists, criminologists, or any other specific sector of non-legal expertise. Quite apart from this need to maintain society-wide political legitimacy as a precondition to institutional effectiveness, we cannot assume that any given claim advanced by a disadvantaged person or group translates - without more input, analysis and testing - into a universally valid moral (let alone legal) prescription. Even when we proactively compose an institution so as to inject "counterprivileging energy" into that institution, the purpose is to make dialogical universalism more of a reality, not to assume normative outcomes before they have been tested through the interaction of diverse views and experiences. ${ }^{116}$

Due to the rough and ready nature of representational indicators, it must be conceded that "representativity" can only ever be a presumption in terms of any given individual. There are men whose understanding of poverty, for example, is such that they have a much better understanding of certain dimensions of the experience of poor women than do many economically privileged women. If we were to accept a contention that something called "representativity" is an absolute requirement for good judgment, we would be denying any faith in the potential of human beings to arrive at understanding through communication across difference. Not only would we have embraced a problematic essentialism, but we would be undercutting the very reason diverse representation is justified in official institutions that exercise judgment on behalf of a wider community namely, the enhancement of dialogical decision-making.

Furthermore, constraints very often are such that affirmative attention to diversity during the structuring of the composition (and decision-making procedures) of a collective institution can easily result in only the most fragmentary approximations of an ideally diverse body. There are all kinds of practical reasons why the actual representation of the most relevant knowledge may not be feasible (or fully feasible) for a given institution or not feasible for a particular stretch of time. These reasons range from the small size of a decision-making body to the logistics of combining expertise and experience for some groups (whose disadvantage is so

${ }^{116}$ Id. 
extensive that educational deficits are endemic) and to the status-quo composition of bodies that (unlike juries) cannot be recomposed for each case. It therefore follows that we must simultaneously attend to other means of ensuring that perspectives not represented within the make-up of the bodies themselves are conveyed in meaningful ways to that body through the myriad kinds of procedures that lawyers both take for granted and are adept at designing (for example, the entering of evidence, the questioning of witnesses, the submission of intervenor briefs and the argument of counsel). There are potentially endless means to be creative about the way that perspectives may be heard by those called upon to judge. $^{117}$

Still, we cannot embrace this ideal of the communicability of human experience to such an extent that we lose sight of the simultaneous (and imperative) need to create the basic conditions of diversity that communicative interaction requires in order for us to attain the richest and truest - understanding of a normative issue. We must equally be aware (and constantly remind ourselves) that to hear is not necessarily to listen.

With this observation, I return to dialogue as the overarching justification for composing an institution on the basis of diversity criteria. I would go so far as to say that we are lost if we do not place considerable faith in a basic capacity for dialogue as both a common human attribute and a capacity we have a duty to develop. If such a capacity is there to be unlocked (as it were), an ethos of dialogue must be valued and cultivated as part and parcel of the creation of the optimal conditions for pursuing justice through collective deliberation. Alongside the enhancement of diversity, an emphasis must accordingly be placed on seeking out people with dialogical disposition: skilled and willing listeners; people aware of the subterranean influences of their own social backgrounds and individual life histories on their assumptions; people able to see many sides of an

\footnotetext{
${ }^{117}$ In the international treaty body context, two of the most crucial procedures are (a) the structured receipt of information from the non-governmental sector and (b) interaction between the stories told in individual communications procedures and the more generalized state report process. On the latter in the context of the monitoring apparatus of the European Social Charter, see Craig Scott and Patrick Macklem, Constitutional Ropes of Sand or Justiciable Guarantees?: Social Rights in a Future South African Constitution 141 U. Pa. L. Rev. 1, 107-08 (1992).
} 
issue without thereby being paralysed by indecision; people who can advocate a position based on a deep commitment without being righteous or dogmatic in doing so; and so on. It would be a mistake to see such an ethos as an avenue to be pursued that is separate from attention to "representativity" (either of experience, or of expertise). Rather both are best seen as co-criteria of any serious effort to enhance an institution's authority. Just as a pluralistic knowledge base is crucial, UN human rights committees must, as much as possible, be composed of individuals who have some underlying disposition to listen to others who are differently situated, to strive to understand those perspectives and to bridge differences in a spirit of dialogue.

\section{RELATING THE RHETORIC OF TRANSNATIONAL REPRESENTATIONAL AUTHORITY TO THE FORMAL POWER OF JudgMENT AND THE (IMAgINED) SCOPE OF COMMUNITY}

It is doubtful that Lauterpacht saw the need to accommodate state concerns and external or imposed judgment as a moral imperative as much as in terms of the pragmatic reality of perceptions of authority in light of the prevailing structure of international legal order. Even at the start of this new millenium, it is difficult to dismiss the normative dimension of state representation outright. Albeit to varying extents, states are perceived as the legal agents for a national society by the members of that society. The state is the normative space in which continuing acts of self-determining choices are made by historically situated political communities such that we may speak, as does Michael Walzer, of the "moral standing of states." 118 It is not only the governmental elites who need to feel that a judgment is, if not an extension of the national, at least an extension of the international to a significant degree rather than being so external as to be foreign. This relates quite closely to the work of theorists like Abdullahi

118 Michael Walzer, The Moral Standing of States: A Response to Four Critics, in International Ethics 217 (Charles Beitz, Marshall Cohen, Thomas Scanlon, \& John A. Simmonds eds., 1985). 
An-Na'im whose work on international human rights emphasizes that standards must be perceived by those to whom they are applicable as selfgiven norms such that the inside must merge with the outside through conjoined processes of intra-societal and cross-societal dialogue. ${ }^{119}$ The question is simultaneously one of legitimacy and effectiveness. Thus, one could say that one must be attentive to the need for a kind of local (to simplify for present purposes, national) ownership of international human rights norms. Many variables will be in play in influencing perceptions in different national cultures, but the eventuality that needs to be planned for is that a judgment in the name of international order may be pervasively regarded within a state as an external imposition. Such an external imposition is unlikely to result in the kind of internalization of norms that leads in the long term to the most deeply rooted compliance. Thus, there is a need to mitigate the problem.

In that respect, one can go the route of Lauterpacht and try to incorporate the national in the international in order to make the external to some extent internal, that is, one can make the external less external, while retaining the legally imposed nature of the judgment. Here, the European Court of Human Rights represents an example, with its retention of national state representation (albeit through only one judge) and the power of binding judgment. Or, one can abandon any pretension that there can be meaningful national representation (thereby accepting the external nature of international judgment) but make the international judgment less than binding as such. That is, the role of imposing the interpretation of the external body can be left as a function of legal processes of conversion of the judgment into judgments internal to the state order itself. Here we have, in effect, the judging processes of the UN human rights treaty bodies. In this second approach, it is the substantive persuasiveness of given judgments and the general institutional authority acquired by virtue of the nature of the institution and its decision-making processes that enter into a dialogical relation with the national social, political and legal processes.

There is one overarching variable that affects perceptions of both the inside/outside and the imposed/non-imposed tensions: the question of the

${ }^{119}$ An-Na'im, supra note 87. 
scope of community. If people feel that a judgment is grounded in a community with which those people feel a part, then judgment will, to that extent, move from the realm of the external into that of the internal; similarly, if judgment emanates from within the community of which the addressee feels a part, then the sense of imposition will give way to a sense of legitimate coercion in the name of the public good. This is of course one of the ways that the European Court has been able to forge greater and greater authority for itself, that is, by promoting and participating in a process of re-imagining itself less as an international court (despite its interstate treaty foundation) than as a constitutional court for a community called "Europe". ${ }^{120}$ But this process of deepening of authority through community-widening has not been paralleled by a corresponding concern with transnationalizing authority through attention to the quality of dialogical interaction within the Court. ${ }^{21}$ The Court is left more often than not with its bare authority of legal position according to which it has the power to bind states to its judgments and appeal implicitly to deference owed to a judgment being brought to bear from within a shared community of the Court, the state-society and "Europe." Yet, there are some, including several European Court of Human Rights judges with whom I have spoken in confidence over the years, who see the formal bindingness of the Court's powers as having had a distinct conservatizing effect on judgments. Bindingness deprives the court of the ability to narrate a judgment that resonates with a human rights ethos, due to the constant attention that needs to be paid to the strategic wisdom of encroaching into still-sovereign space. The Court's formal power to bind with its judgment does not allow - at least, has not been interpreted by the Court as allowing - an active role for the court by way of issuing robust 'judgments' that rely on their persuasive value rather than on the bald juridical fact of their formal bindingness in order to have an impact on social and political debate in the states in question. On the rare occasion in

${ }^{120}$ Loizidou v. Turkey, judgment of 23 March 1995, European Court of Human Rights, Series A, No. 310, para 93: "In addressing this issue the Court must bear in mind the special character of the Convention as an instrument of European public order ('ordre public') for the protection of individual human beings and its mission, as set out in Article 19, 'to ensure the observance of the engagements undertaken by the High Contracting Parties""

${ }^{121}$ See Scott, supra note 83, on European Court, including the thin beginnings of attention to gender representation. 
which the Court has tried to finesse matters by bringing some normative influence to bear through the technique of judicial hinting about future rulings (for example, in the area of the recognition of transsexual selfidentity), ${ }^{122}$ these hints have always been forced into the mould of a warning about a future binding judgment.

There are a good number of instances where it can be plausibly argued that the Court felt so constrained by the spectre of having to bind a state to a finding of a violation that they saw the issue of whether to adopt a purposive interpretation of a right as a choice between imposing their judgment and adopting a sound evolutionary interpretation. One such instance is the role played by the Court in Johnston v Ireland in which the issue of whether the right to marry included a right to divorce was at stake. ${ }^{123}$ Not having the option (or, at least, not seeing itself as having the option) to pursue a course of injecting a European normative voice into the charged political debates in Ireland in a non-binding (recommendatory or advisory) fashion, the Court opted out entirely from probing the range of intersecting factors that spoke in favour of analysing the constitutional ban on divorce in Ireland as a European Convention human rights question (including such factors as women's equality and consistency with earlier and, it turned out, later - jurisprudence on a 'freedom to $\mathrm{X}$ ' entailing also a 'freedom not to $X$ '). The normative debate in Ireland over divorce thus continued for a number of years, more or less uninfluenced by any European human rights perspective, before a referendum narrowly approved removal of the constitutional ban.

It is not my purpose in this concluding section unequivocally to endorse non-binding judicial powers as the ideal partner of an enhancement of the diversity of knowledge within the processes of interpretive persuasion of international human rights adjudication. I do wish to signal what I see as a worthwhile direction for future theorizing to take, however. At the moment, I limit myself to the claim that, at minimum, having such remedial flexibility could well increase the extent to which international bodies will be willing to adopt what they feel are the most justifiable

\footnotetext{
${ }^{122}$ See Rees v. United Kingdom, 106 Eur. Ct. H.R. (ser. A) (1986) and Cossey v. United Kingdom, 184 Eur. Ct. H.R. (1990).

${ }^{123}$ Johnston v. Ireland, supra note 57.
} 
human rights interpretations even when they are concerned about the fact or perception of undue intrusion into a national or subnational community's political debate on an obviously controversial matter. As for future avenues of exploration, the case for dialogical interaction and transnational community-building through non-binding forms of institutional judgment will likely be married to an argument that international bodies must nonetheless retain some form of legally determinative power when it comes to the question of evaluating whether a given state has complied with the primordial duty of creating the legal avenues in its domestic order that allow that state's own judiciary full scope to consider whether the international human rights treaty in question has been breached. Such a twin-track approach (persuasive judgments on 'substantive' matters and binding judgments on the 'procedural' question of whether domestic law adequately gives legal effect to the treaty in its domestic order) will, it seems to me, create the most promising avenue for combining effectiveness and legitimacy in international human rights protection. In this way, within an overarching framework of dialogical universalism, we will have moved from rhetoric to representation and back to rhetoric again in the quest for a theory of international interpretive authority that can inform the institutional design of any future international human rights court. ${ }^{124}$

124 Although the point cannot be elaborated upon here, the most promising conceptualization to date of the linkages between international human rights treaty law and the domestic orders of states parties would seem to have been provided by Committee on Economic, Social and Cultural Rights', "The Domestic Application of the [International] Covenant [on Economic, Social and Cultural Rights]", General Comment No. 9, UN Doc E/C.12/1998/24, December 1998. 